OPEN ACCESS

Edited by:

Zafar Reshi,

University of Kashmir, India

Reviewed by:

Rajesh Tandon,

University of Delhi, India

Veenu Kaul,

University of Jammu, India

*Correspondence:

Susheel Verma

eremurus@rediffmail.com

Specialty section:

This article was submitted to

Functional Plant Ecology,

a section of the journal

Frontiers in Plant Science

Received: 23 April 2021 Accepted: 03 January 2022 Published: 17 February 2022

Citation:

Wani IA, Verma S, Ahmad $P$, El-Serehy HA and Hashim MJ (2022)

Reproductive Biology of Rheum

webbianum Royle, a Vulnerable Medicinal Herb From Alpines of North-Western Himalaya.

Front. Plant Sci. 13:699645. doi: 10.3389/fpls.2022.699645

\section{Reproductive Biology of Rheum webbianum Royle, a Vulnerable Medicinal Herb From Alpines of North-Western Himalaya}

\author{
Ishfaq Ahmad Wani' ${ }^{1}$, Susheel Verma ${ }^{*}$, Parvaiz Ahmad ${ }^{2}$, Hamed A. El-Serehy ${ }^{3}$ and \\ Maha J. Hashim ${ }^{4}$ \\ 'Conservation and Molecular Biology Lab, Department of Botany, Baba Ghulam Shah Badshah University, Rajouri, India, \\ ${ }^{2}$ Department of Botany and Microbiology, King Saud University, Riyadh, Saudi Arabia, ${ }^{3}$ Department of Zoology, College \\ of Science, King Saud University, Riyadh, Saudi Arabia, ${ }^{4}$ Department of Bioscience, University of Nottinghamshire, \\ Nottingham, United Kingdom
}

Information on reproductive biology and pollination ecology studies of threatened plants are essential to develop strategies for their sustainable utilization and effective conservation. As such, these studies were conducted on Rheum webbianum, a highvalue "vulnerable" medicinal herb of the north-western Himalaya. This species presents a unique mode of reproductive behavior through the involvement of different floral events, including the movement of reproductive organs. The plants survive extremely cold conditions through underground perennating rhizomes that sprout into juvenile shoots with the onset of the favorable climatic conditions. The peduncle arises from the axils of the radical leaves, bearing a globular collection of densely arranged hermaphrodite flowers with temporally separated male and female phases; the male phase precedes the female phase (protandry). Anther dehiscence and stigma receptivity is post-anthesis. Anthers dehisce longitudinally along margins, liberating a large mass of spherical and tricolpate pollen with spinulose exine. Pollen viability decreased to $<10 \%$ on day 9. Pistil is tristylous, with each style terminating into a fan-shaped stigma lobe. The pollen receptive surface of each stigmatic lobe remains incurved at an angle of $360^{\circ}$ and shows upward movement after anthesis, forming a funnel-like structure at an angle of $180^{\circ}$ with respect to the ovary. Pollination syndrome is ambophilous. Spontaneous autogamy or geitonogamy to a certain extent is achieved in this species due to the arrangement of flowers in the inflorescence and overlapping of male and female reproductive phases among them. Incurved stigmatic lobes and outward movement of stamens too facilitate outcrossing. Pollen/ovule ratio estimates, results of pollination experiments on breeding behavior, outcrossing, and self-compatibility indices demonstrated that plants are self-compatible and cross-fertile.

Keywords: Rheum webbianum, hermaphrodite, protandry, incurved stigma, mixed mating, ambophilous, outcrossing 


\section{INTRODUCTION}

The genus "Rheum" belongs to the family Polygonaceae and was first reported by Carl Linnaeus in 1753 (Linnaeus, 1753). Globally, this genus is represented by about sixty perennial species distributed in the mountains of Asia and Europe (Kao and Cheng, 1975; Li, 1998). In the Indian subcontinent, this genus is represented by seven species (Ganie et al., 2014), all of them are present in Kashmir Himalaya (Stewart, 1972). Rheum webbianum is an important species of this genus inhabiting alpine regions between 2,400 and 4,300 m.a.s.l (Agarwal et al., 2001; Rashid et al., 2014; Tabin et al., 2016). Commonly known as "Pambhak" (leaves) or "Pambchalan" (rhizome), it is medicinally important finding wider utilization in the pharmaceutical sector in the preparation of drugs combating cancer (Srinivas et al., 2007) and body cholesterol (Abe et al., 2000). It is also highly important in treating indigestion, abdominal disorders, boils, wounds, and gastritis through traditional medicinal practices (Chaurasia and Ballah, 2009; Tabin et al., 2016). Incessant exploitation of the plant along with cattle grazing and trampling has threatened its existence in nature. Unprecedented overexploitation has squeezed its populations and as such, it has been listed as a vulnerable medicinal herb from North-West Himalaya (CAMP, 2003; Ved et al., 2003; Tali et al., 2014). In Kashmir Himalaya, which constitutes a part of North-West Himalaya, $R$. webbianum grows at higher elevations between 2,836 and 4,497 m.a.s.l. (Wani et al., 2021).

It has been observed more frequently that at higher elevations, plants exhibit greater phenotypic plasticity as it enables them to adapt to the highly variable environment there (Stocklin et al., 2009; Pluess et al., 2011). Plants adjust key physiological and reproductive processes (Korner et al., 1989; Becker et al., 2006; Korner, 2007) as well as morphological traits (Phillips et al., 2011) in response to the climatic shifts. It has also been reported that phenotypic plasticity allows to compensate the short growing season of plants by allowing rapid reproduction in some alpine and subalpine species (Stinson, 2004). Reproduction is an important and fragile step in the life history of the plants and a prerequisite natural process to multiply, evolve, and survive ( $\mathrm{Li}$ et al., 2018). Therefore, detailed knowledge on different attributes of reproductive biology (flowering phenology, breeding system, pollinator availability, pollination and reproductive success, seed and fruit formation, seed germination and seedling recruitment) is indispensable for determining the nature of species adaptation. Such studies bring into account the reproductive bottlenecks of plants and greatly aid in designing effective conservation strategies (Moza and Bhatnagar, 2007; Bentos et al., 2008; Kaur et al., 2013; Gopalakrishnan and Thomas, 2014; Sreekala, 2017). These studies also provide valuable information on speciation, adaptation, hybridization, and systematics (Anderson et al., 2002; Neal and Anderson, 2005). Mating and breeding systems are the integral components of plant reproduction as they determine the genetic structure of populations (Schemske and Lande, 1985) and also drive the evolutionary changes in closely related species (Brauner and Gottlieb, 1987; Ashman, 2003).

There is ample information that plant-pollinator interaction determines the success of sexual reproduction (Gan et al., 2013;
Castano et al., 2014) and understanding of seed biology (germination and development) is important in the quality improvement and cultivation of medicinal plants (Bareke, 2018). While a large group of pollinators is generalists (Ollerton, 2014), there are some specialists, which have evolved throughout the course of evolutionary history (Proctor et al., 1996; Endress and Bruyns, 2000). Loss of variability among the populations and inbreeding depression are the inevitable consequences of self-pollination. Outcrossing is believed to be the most evolved form of breeding system (Evans et al., 2003; Mayer et al., 2011; Nebot et al., 2016; Sreekala, 2017). Several plant species are known to possess specific adaptive strategies to combat the loss of pollinators and to modify their breeding system toward a more favorable mode, that is, outcrossing. In certain cases, selfing is avoided by plants to promote outcrossing through stylar movement (Verma et al., 2004). Under certain limiting circumstances when pollination fails, the plants move their styles to get pollinated and assure reproduction (Ruan et al., 2009; Khajuria et al., 2011).

The present study was therefore carried out to understand the variation in growth characteristics, reproductive success, and pollinator behavior of $R$. webbianum in relation to the habitat variability at high altitude areas of Zanskar and Pir Panjal mountain ranges of Kashmir Himalaya. This study also aimed at designing strategies for conservation, cultivation, and sustainable use of wild populations, as well as to identify the most suitable and productive habitats for the growth of $R$. webbianum.

\section{MATERIALS AND METHODS}

\section{Study Area and Plant Identification}

The present study was conducted from May 2017 to September 2020 at the Zanskar and Pir Panjal subranges of the northwestern Himalaya extending through Ladakh and Kashmir union territories (UTs) of India. Fieldwork was carried out in three different regions: Panikhar, Kargil (PK) $\left(34^{\circ} 07^{\prime} 08.442^{\circ} \mathrm{N}\right.$; $\left.75^{\circ} 57^{\prime} 06.254^{\circ} \mathrm{E}\right)$, Katarkhal, Shopian (KS) $\left(34^{\circ} 13^{\prime} .721^{\circ} \mathrm{N}\right.$; $\left.75^{\circ} 57^{\prime} .912^{\circ} \mathrm{E}\right)$, and Tiken Batpora, Pulwama (TBP) (33.8481 $\left.\mathrm{N}, 74.8697^{\circ} \mathrm{E}\right)$. The population at Panikhar lies in the Zanskar region and was located at an altitude of 3,327 m.a.s.l. Katarkhal lies in the Pir Panjal mountain range and the population was located at an altitude of 3,474 m.a.s.l. The population at Tiken Batpora was an introduced population, which was maintained in a conservatory under ex situ conditions. At all the sites, the species was studied throughout its different phenophases, and necessary data were recorded and subjected to further analysis.

The species was identified by consulting the herbarium specimens and published data. The specimens collected during the present study were compared with the specimens submitted under voucher numbers 19293, 31398, 31399 at Herbarium of Department of Botany, Punjabi University, Patiala and 31204 at Kashmir University Herbarium. Earlier published records related to morphology and distribution of this species were also referred for identification (Sagoo and Farooq, 2011; Baig et al., 2014; Tali et al., 2014; Tabin et al., 2016; Ganie et al., 2017). 


\section{Phenology}

The data were collected on different phenophases immediately after the sprouting of rhizomes until senescence in all 3 populations. Phenological events (sprouting, vegetative phase, flowering, fruiting, seed maturation, and senescence) were monitored on tagged plants (seven plants from each site) at their three locations on a population basis. During the flowering period, observations were carried out on a daily basis, while for fruit and seed traits, the observations were carried out once a week (Tandon et al., 2003; Verma et al., 2003, 2004; Smitha and Thondaiman, 2016).

\section{Floral Traits and Biology}

Twenty-one mature and healthy plants (7 from each population) with full bloom were randomly selected and tagged to study floral traits and biology. A detailed study regarding different quantitative characteristics of floral parts, namely, length and width of the anther, stamen length, stigma length and width, ovary length, ovary width, and the size of ovule, was carried out under a stereo zoom microscope (Olympus- BX51). The number of flowers per inflorescence, number of anthers per flower, length of inflorescence, and length of the peduncle were noted directly in the field with applied SDs.

Principal component analysis (PCA) was performed to investigate whether the plant populations sampled at the three sites differed in the studied morphological and reproductive characters. It simplifies the complexity of data set by reducing it to those variables that show a higher contribution to give the best summary of the data using a limited number of PCs. We used the "stats" package for PCA analysis and "ggbiplot" for plotting the respective ordination biplot. All the analyses were performed in R software v.4.0.3 (R Core Team, 2020), using the packages cited within.

\section{Anthesis Time and Direction of Anther Dehiscence}

The time of blooming of individual flowers and inflorescences was observed on open flowers from all the populations. Filament movement and anther dehiscence were observed on the same flowers $(n=20)$ with the help of a hand lens and protector (Nautiyal et al., 2009; Li et al., 2018). The direction of anther dehiscence with respect to the stigma was determined as the degree of movement of the filaments of the bithecous anthers relative to their initial position.

\section{Pollen Stainability, Viability, and the Pollen-Ovule Ratio}

The stability and viability of pollen were determined using $1 \%$ Fluorescein diacetate (FDA) and acetocarmine and (Shivanna and Rangaswamy, 1992). The number of viable and nonviable pollen grains was counted under a Nikon 80i eclipse microscope at $10 \mathrm{x}$ magnification. The pollen-ovule ratio was calculated by counting the number of pollen grains per anther and then multiplying the figure by the number of anthers per flower. The ovule count was determined by treating ovaries with $4 \mathrm{~N} \mathrm{NaOH}$ for $12-14 \mathrm{~h}$ at $60^{\circ} \mathrm{C}$ and washing them to remove traces of $\mathrm{NaOH}$. Finally, the ovaries were squashed in Lewis stain and visualized under a microscope. The pollen-ovule ratio was calculated following Verma et al. (2008).

\section{Stigma Receptivity}

The stigma receptivity was checked by fixing hand-pollinated stigmas of different ages (21 stigmas from 7 plants) in Carnoy's fixative containing absolute alcohol and glacial acetic acid at a ratio of 3:1. After a predefined time $(2-4 \mathrm{~h})$, these stigmas were transferred to $70 \%$ alcohol until further use. For microscopic examination, pistils were stained with Lewis stain (mixture of $2 \mathrm{ml}$ of $1 \%$ aq. Acid fuchsin, $2 \mathrm{ml}$ of $1 \%$ aq. light green and $40 \mathrm{ml}$ lactic acid and $46 \mathrm{ml}$ distilled water) (Lewis, 1979) and in aniline blue for fluorescence microscopy (Shivanna and Rangaswamy, 1992; Khajuria, 2013). The stigmas that showed pollen germination were considered receptive.

The hydrogen peroxide $\left(\mathrm{H}_{2} \mathrm{O}_{2}\right)$ method was also used to determine stigma receptivity, wherein bubbling in the presence of $\mathrm{H}_{2} \mathrm{O}_{2}$ is considered to be a positive result (Li et al., 2018). Twentyone stigmas from 7 plants were subjected to the treatment to determine the stigma receptivity.

\section{Breeding Behavior}

To understand the breeding system in $R$. webbianum, healthy buds that would definitely bloom were selected randomly and tagged. At flower anthesis, six different manual pollination treatments were executed.

\section{Apomixis or Agamospermy}

During bud condition or at the time of anthesis, emasculation was performed in buds $(n=150)$ for each population followed by bagging with butter paper bags $(1.5 \times 2 \mathrm{~cm})$ to prevent pollen deposition by wind or insects. The tagged buds were regularly monitored for fruit set, if any.

\section{Unassisted Pollination, Spontaneous Autogamy, or Autonomous Selfing}

Flower buds were bagged $(n=150)$ for each population for unassisted pollination. The bags were removed after the completion of the reproductive phase.

\section{Selfing or Facilitated Autogamy}

Emasculated flowers were manually pollinated with pollen of the same flower followed by bagging.

\section{Geitonogamy}

Emasculated flowers were manually pollinated with the pollen of other flowers from the same plant, followed by bagging.

\section{Xenogamy}

Emasculated flowers were bagged until the stigmas of these flowers were manually pollinated with pollen collected from different individuals of the same population. Such flowers were bagged to avoid any contamination from self or geitonogamous pollen. 


\section{Control}

The flowers were kept as such for open pollination and observed for fruit and seed set after flowering was complete.

Two-way ANOVA was performed to evaluate simultaneously the effect of site and treatment on the development of fruit and seed.

\section{Outcrossing Index, Index of Self-Incompatibility, and Inbreeding Depression}

The outer crossing index (OCI) was calculated following the methods of Dafni (1992) and Barman et al. (2018) (Table 1). The mean scores of flower diameter, placement of anthers and stigma, and time of anther dehiscence and stigma receptivity were added to obtain the possible results (Table 2).

The index of self-incompatibility was determined by calculating the percentage of average fruit set from manual self-pollination to manual cross-pollination. Values below or equal to 0.2 depict self-incompatibility and values greater than this level show self-compatibility. Inbreeding depression was calculated following the method of Ramirez and Nassar (2017). The difference in the level of inbreeding depression between the three sites was ascertained through one-way ANOVA and will help us to analyze the loss of vigor with respect to different pollination treatments.

$$
\mathrm{ID}=1-(\omega \mathrm{s} / \omega \mathrm{o})
$$

Where $\omega s=$ mean seed weight of self-pollinated seeds; $\omega \mathrm{o}=$ mean seed weight of cross-pollinated seeds.

TABLE 1 | Observations of different floral parameters to determine outcrossing index of Rheum webbianum (following Dafni, 1992).

\begin{tabular}{llc}
\hline Observation & Expression & Value \\
\hline Flower diameter & $<1 \mathrm{~mm}$ & 0 \\
& $1-2 \mathrm{~mm}$ & 1 \\
& $2-6 \mathrm{~mm}$ & 2 \\
& $>6 \mathrm{~mm}$ & 3 \\
Anther dehiscence and & Homogamy & 0 \\
stigma receptivity & Protogyny & 0 \\
& Protandry & 1 \\
Position of stigma and & Anthers and stigma at the same level & 0 \\
anthers & Separated and contact not possible & 1
\end{tabular}

TABLE 2 | Outcrossing index value vis-a-vis type of breeding system (following Dafni, 1992).

\begin{tabular}{ll}
\hline $\begin{array}{l}\text { Outcrossing } \\
\text { index value }\end{array}$ & $\begin{array}{l}\text { Breeding system (flower diameter + anther dehiscence } \\
\text { and stigma receptivity + Position of stigma and anthers) }\end{array}$ \\
\hline 0 & Cleistogamy \\
1 & Obligate autogamy \\
2 & Facultative autogamy \\
3 & Predominantly self-pollinated \\
4 & Mixed mating \\
5 & Predominantly cross-pollinated
\end{tabular}

\section{Seed Germination}

The dry weights of 6-month-old seeds (50 seeds with four replicates from each site) obtained from auto-, geitono-, and xenogamy were recorded. The seeds were soaked in water at $19 \pm 1.7^{\circ} \mathrm{C}$, removed at equal intervals, wiped dry, weighed, and soaked again until a constant weight was obtained. The seeds were subsequently placed in plastic plates $[22.5 \times 4 \mathrm{~cm}(1 \times \mathrm{h})]$ containing vermicompost and monitored for germinability. Percentage of seed germination and seedling survival were recorded.

\section{Pollination Ecology}

The pollination censuses were conducted at peak flowering periods during three consecutive seasons from 2017 to 2019. The pollination efficiency was measured in terms of pollen load deposited on the stigma of the flowers at the first visit of the pollinator. It was calculated from 30 different flowers (10 each from different populations) following Singh et al. (2014). Pollinated stigmas were stained with $0.2 \%$ acetocarmine, and the total number of pollen deposited was checked under a light microscope at $40 \times$. To ascertain anemophily, glass slides smeared with Mayer's albumen were hung from wooden stands kept around the plants for $24 \mathrm{~h}$ and finally observed under a light microscope for pollen deposition (Khajuria, 2013). Entomophily was determined on keen observations in the field for 1 week during peak flowering. A large number of flowers were emasculated at the onset of the night at Panikhar and Tiken Batpora populations and kept unbagged throughout the night. Stigmas of such flowers were clipped early in the morning, fixed in Carnoy's fixative (3 parts absolute alcohol:1 acetic acid), transferred to $70 \%$ alcohol after $4 \mathrm{~h}$, and observed later on for pollen load and germination.

Different pollination indices were calculated for all the pollinators to determine their contribution to pollen transfer. The foraging behavior (FB) of insect visitors was ascertained through direct field visitations at regular intervals of time. It was determined as the time spent by a particular pollinator per inflorescence per visit (Sajjad et al., 2009; Yaqoob and Nawchoo, 2016). Foraging speed (FS) was calculated as the average number of flowers visited per minute of time (Pando et al., 2011; Yaqoob and Nawchoo, 2016). Insect visitation efficiency (IVE) and insect visitation frequency (IVF) were determined following the methodology put forward by Yaqoob and Nawchoo (2016).

The one-way ANOVA test was performed to study the statistical significance of different pollinators in the transfer of pollen and to determine the pattern of pollen deposition on the different body parts of the pollinators.

\section{RESULTS}

\section{Habitat and Phenology}

Rheum webbianum Royle (Polygonaceae) is a perennial stout rhizomatous herb that grows on the exposed rocky terrain of alpine and subalpine zones of the Panikhar and Katarkhal 
regions. Observations pertaining to the time period of leaf flushing, flowering, fruiting, seed formation, and senescence reveal that a plant completes its life cycle within a period of 6-7 months. It overcomes harsh winters in the form of dormant underground rhizomes. With the onset of the spring season, growth resumes and the dormant rootstock sprouts into juvenile shoots. Increased temperature and photoperiod release the dormancy of perennating rhizomes, and the time period of this activity has been observed to be different at different locations. An earlier outburst of cauline leaves was seen in populations growing at TBP compared with populations growing at KS and PK. The plants bear terminal, branched inflorescences that remain enclosed in a sheath before the onset of anthesis, and they bear densely arranged hermaphrodite flowers. The peduncle attains a length of $0.5-1.5 \mathrm{~m} \pm 0.6$ feet. The wilting of tepals from their margins and their inward bending movement acts as a signal of phenophase shift from flowering to fructification. As the fruit ripens, the bracts wither leaving behind ragged stems covered with panicles of deep brown pendulous fruits bearing albuminous seeds. Most of the leaves dry after yellowing and remain persistent on the parent plant by thick and leathery petioles. Detailed phenological events are shown in Figures 1A,B.

\section{Morphometric Analysis, Floral Traits, and Floral Biology}

The plants of $R$. webbianum in different populations showed significant differences with respect to their morphological characters. The lowest values for morphological characters were recorded for the KS population growing at the highest elevation and the highest values were observed for the TBP population. The plant body is differentiated into a thick rhizome that penetrates deep into the soil. The size of rhizome varies from 14 to $55 \mathrm{~cm}$. The leaves are dark green, thick, and glabrous and attain the size of $19 \pm 8$ (width) and $33 \pm 13.3$ (length) $\mathrm{cm}$. Each flower of $R$. webbianum has creamish white campanulate and hairless perianth represented by six tepals. The lifespan of individual flowers (from anthesis up to swelling of the ovary) and inflorescences was approximately $9 \pm 3.02$ and $18 \pm 3.03$ days, averaging across all the sites. The flowers are completely zygomorphic, bisexual, and

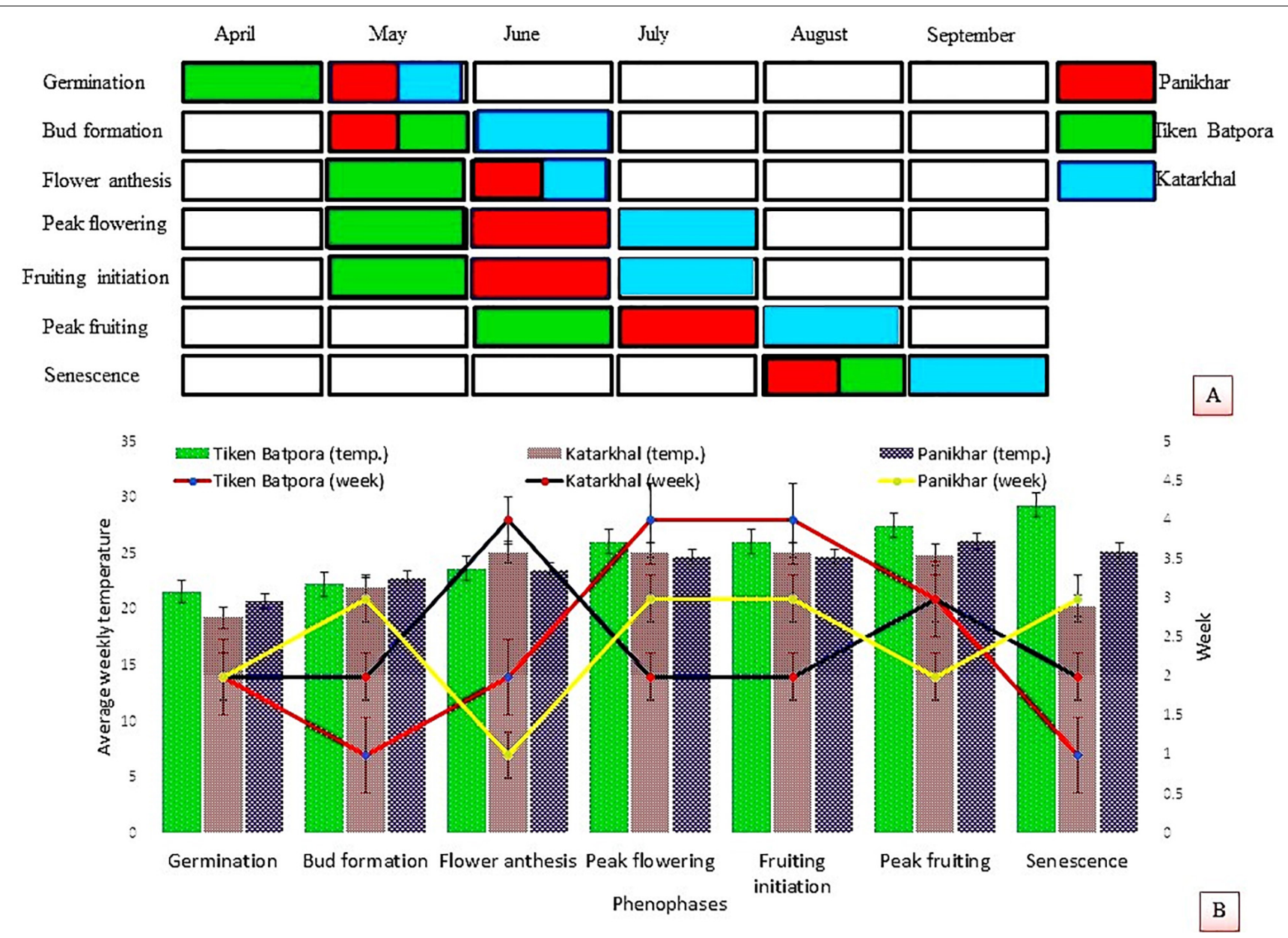

FIGURE 1 | (A) Phenophases of Rheum webbianum at in situ and ex situ populations. (B) Response of different phenophases to average weekly temperature and time periods. 
protandrous. Androecium is represented by 9 stamens with elliptical, bithecous, free or subconnate, pale yellow anthers with filaments inserted on the torus at the base of the perianth. The gynoecium is represented by a single carpel with one ovule. The pistil is tristylous with a single triangular ovary and three erect or deflexed styles, each terminating to a fan-shaped stigma lobe. The nectaries form a ring at the base of the ovary. The fruits are threesided achenes, oblong or orbicular, notched at both ends. The fruits are light green in color, which turn reddish-brown upon maturity. Complete morphological details of the floral parts are given in Table 3.

Based on the Kaiser-Guttman criterion, only the first two PCs retained the variation greater than the average eigen value and thus were used for plotting the PCA biplot. Overall, the first two PCs retained about $80 \%$ of the total variation in the dataset. The principal component 1 (PC1) contributing about $60 \%$ of the variation mainly served to separate the populations of $\mathrm{PK}$ and KS from the TBP site. Although, majority of the variables were associated with this component, however, the most contributing

TABLE 3 | Morphometric analysis of floral characters of Rheum webbianum across three different study areas.

\begin{tabular}{|c|c|c|c|}
\hline Floral trait & TBP & PK & KS \\
\hline $\begin{array}{l}\text { Length of a } \\
\text { flower }\end{array}$ & $1.5 \pm 0.3 \mathrm{~cm}$ & $1.7 \pm 0.3 \mathrm{~cm}$ & $1.6 \pm 0.2 \mathrm{~cm}$ \\
\hline $\begin{array}{l}\text { Width of a } \\
\text { flower }\end{array}$ & $0.9 \pm 0.3 \mathrm{~cm}$ & $1.1 \pm 0.3 \mathrm{~cm}$ & $1.1 \pm 0.2 \mathrm{~cm}$ \\
\hline Tepal length & $6 \pm 1.4 \mathrm{~mm}$ & $6 \pm 1.6 \mathrm{~mm}$ & $5 \pm 0.3 \mathrm{~mm}$ \\
\hline Tepal width & $4 \pm 0.9 \mathrm{~mm}$ & $3.8 \pm 0.8 \mathrm{~mm}$ & $3.9 \pm 0.7 \mathrm{~mm}$ \\
\hline Length of anther & $594.1 \pm 24.60 \mu \mathrm{m}$ & $771.8 \pm 17.07 \mu \mathrm{m}$ & $697.9 \pm 21.01 \mu \mathrm{m}$ \\
\hline Width of anther & $307.52 \pm 11.09 \mu \mathrm{m}$ & $359.9 \pm 15.5 \mu \mathrm{m}$ & $352 \pm 7.7 \mu \mathrm{m}$ \\
\hline $\begin{array}{l}\text { Length of } \\
\text { dehiscence line }\end{array}$ & $569.39 \pm 4.98 \mu \mathrm{m}$ & $678.45 \pm 4.39 \mu \mathrm{m}$ & $672 \pm 4.12 \mu \mathrm{m}$ \\
\hline $\begin{array}{l}\text { Connective } \\
\text { length }\end{array}$ & $203 \pm 13.93 \mu \mathrm{m}$ & $227.50 \pm 21.17 \mu \mathrm{m}$ & $235.14 \pm 19 \mu \mathrm{m}$ \\
\hline Pollen length & $2.571 \pm 0.27 \mu \mathrm{m}$ & $3.39 \pm 0.22 \mu \mathrm{m}$ & $3.27 \pm 0.32 \mu \mathrm{m}$ \\
\hline Pollen width & $2.12 \pm 0.19 \mu \mathrm{m}$ & $2.97 \pm 0.25 \mu \mathrm{m}$ & $2.52 \pm 0.15 \mu \mathrm{m}$ \\
\hline $\begin{array}{l}\text { Length of } \\
\text { stamen }\end{array}$ & $1.4 \pm 0.3 \mathrm{~cm}$ & $1.7 \pm 0.28 \mathrm{~cm}$ & $2.2 \pm 0.35 \mathrm{~cm}$ \\
\hline $\begin{array}{l}\text { Stigma lobe } \\
(w \times b)\end{array}$ & $\begin{array}{c}469.39 \times 518.72 \pm \\
27.7 \times 19.9 \mu \mathrm{m}\end{array}$ & $\begin{array}{l}639.22 \times 675.9 \pm \\
56.59 \times 47.07 \mu \mathrm{m}\end{array}$ & $\begin{array}{l}616.89 \times 637.7 \pm \\
57.21 \times 42.02 \mu \mathrm{m}\end{array}$ \\
\hline Style $(1 \times b)$ & $\begin{array}{c}172.96 \times 79.06 \pm \\
21 \times 14.05 \mu \mathrm{m}\end{array}$ & $\begin{array}{c}178.88 \times 81 \pm \\
19.5 \times 14.09 \mu \mathrm{m}\end{array}$ & $\begin{array}{l}175.9 \times 80.12 \pm \\
21.5 \times 19.50 \mu \mathrm{m}\end{array}$ \\
\hline $\begin{array}{l}\text { Ovary length } \\
(20 x)\end{array}$ & $1329.76 \mu \mathrm{m}$ & $1165.017 \mu \mathrm{m}$ & $1409.58 \mu \mathrm{m}$ \\
\hline $\begin{array}{l}\text { Ovary width } \\
(20 \times)\end{array}$ & $945.551 \mu \mathrm{m}$ & $770.796 \mu \mathrm{m}$ & $978.431 \mu \mathrm{m}$ \\
\hline Length of ovule & $601.552 \mu \mathrm{m}$ & 559. $775 \mu \mathrm{m}$ & $641.730 \mu \mathrm{m}$ \\
\hline Width of ovule & $361.14 \mu \mathrm{m}$ & $311.283 \mu \mathrm{m}$ & $374.40 \mu \mathrm{m}$ \\
\hline Seed length & $2 \mathrm{~mm}$ & $2 \mathrm{~mm}$ & $2 \mathrm{~mm}$ \\
\hline Seed width & $1 \mathrm{~mm}$ & $1 \mathrm{~mm}$ & $1 \mathrm{~mm}$ \\
\hline $\begin{array}{l}\text { Length of } \\
\text { inflorescence }\end{array}$ & $38.2 \pm 8.4$ inch & $32.5 \pm 6.6$ inch & $20.9 \pm 4.7$ inch \\
\hline $\begin{array}{l}\text { Width of } \\
\text { inflorescence }\end{array}$ & $16.7 \pm 5.4$ inch & $14.4 \pm 4.7$ inch & $12.4 \pm 4.7$ inch \\
\hline $\begin{array}{l}\text { Number of } \\
\text { flowers }\end{array}$ & $1,346 \pm 303.9$ & $1,098 \pm 241.4$ & $784 \pm 127.3$ \\
\hline
\end{tabular}

variables were the width of anther (AW), stamen width (STW), ovary length (OL), seed width (SW), style width (STLW), stamen length (STLL), and style length (SYL). Similarly, the principal component 2 (PC2) contributed about $20 \%$ of the variation in the dataset. Tepal length (TL), tepal width (TW), flower width (FW), flower number (FN), leaf size (LS), inflorescence length (LI), and length of rhizome (LR) were the most governing variables associated with this component (Figure 2).

\section{Anthesis and Anther Dehiscence}

The flowers in the inflorescence do not show any particular fashion of opening. On an average, a flower took $2.4 \mathrm{~h} \pm 20 \mathrm{~min}$ to open completely across all the study areas. The flowers began to open between 6:00 and 9:00 h, which continued till 14:15-16:30 h. Maximum flowers opened between 9:00 and 12:00 h (Table 4). None of the flowers open at night. A flower bears 9 stamens, each bearing a bithecous anther that faces toward the stigma (introrse). During bud condition, the filaments lie at an angle of $17^{\circ}$ with respect to the ovary. However, elongation of stamens and their movement bring stamens at an angle of $70^{\circ}$ with respect to the ovary at the time of anther dehiscence. The anthers are placed at an angle of $80^{\circ}$ with respect to their filaments with the line of dehiscence facing toward the upper side. The anther dehiscence started at approximately $37.25 \pm 3.3 \mathrm{~h}$ after flower anthesis. The anthers may or may not dehisce simultaneously. Dehiscence occurs along margins releasing a large number of pollen grains. The flowers may or may not shed all their pollen. Undehisced anthers wilt with their pollen inside and degenerate. The Tepals along with stamens then show inward movement and finally wither, which acts as a signal for fructification (Figures 3A-E).

\section{Pollen Morphology, Viability, and the Pollen-Ovule Ratio}

During bud condition, the pollen is yellowish and become creamish white later on. Light and fluorescence microscopy revealed that the pollens are spherical and tricolpate. Exine bears spinulose sculpturing. The diameter of the pollen grain ranges between $2.57 \pm 0.27 \mu \mathrm{m}$ and $3.39 \pm 0.22 \mu \mathrm{m}$. They are oval in shape. Pollen viability was observed at the time of anthesis, which showed a sharp decreasing trend and decreased to $<10 \%$ on day 9 . Based on the daily average basis, pollen viability trend decreases between 09:00 and 21:00 h $(09: 00>12: 00>15: 00>18: 00>$ 21:00 h). The highest pollen viability as determined by the FDA test and $1 \%$ acetocarmine was reported at Panikhar (83 \pm 4.2 and $87 \pm 4.73 \%)$, followed by Tiken Batpora and Katarkhal ( $82 \pm 4.98$ and $86 \pm 5.3 \%$ ) (Figure 4). The pollen: ovule ratio was 7,000 $\pm 868: 1$, $6,086 \pm 672: 1$, and 4,987 \pm 478:1 per flower at Panikhar, Katarkhal, and Tiken Batpora, respectively.

\section{Stylar-Stigmatic Movement and Stigma Receptivity}

The flowers are monocarpellary with a single pistil having three styles each terminating into a stigma. Fan-shaped stigmatic lobes are wet and fleshy. The styles are deflexed at an angle of $60^{\circ}$ with respect to each other. Each stigmatic lobe has many small lobules. 


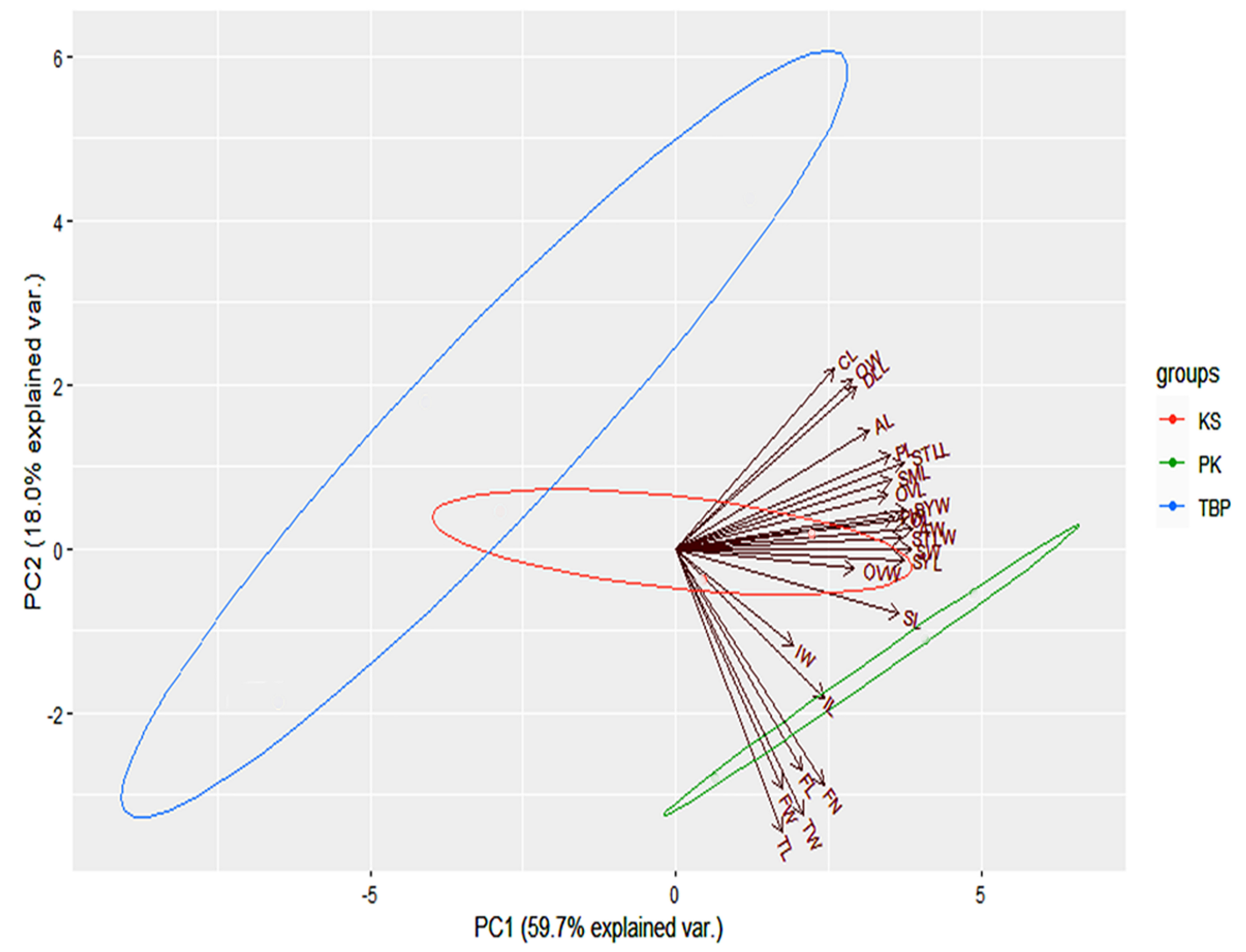

FIGURE 2 | Ordination biplot of the morphological variables at three studied sites. Directions along with the magnitudes of the variables driving each axis are also shown.

TABLE 4 | Pattern of flower anthesis and anther dehiscence.

\begin{tabular}{|c|c|c|c|c|c|c|c|c|}
\hline Area & Anthesis & Time & Duration & Maximum & Completion & Anther dehiscence & Timing & Direction \\
\hline TBP & May & 6:00 a.m. \pm 14 min & $2.4 \mathrm{~h} \pm 20 \mathrm{~min}$ & $83 \% \pm 5.8$ at $09: 30$ a.m. $\pm 15 \mathrm{~min}$ & $14: 15 \mathrm{~h} \pm 20 \mathrm{~min}$ & $31.48 \pm 1.58 \mathrm{~h}$ & $A$ & $80-120^{\circ}$ \\
\hline KS & June & $07: 15$ a.m. $\pm 21 \mathrm{~min}$ & $2.4 \mathrm{~h} \pm 37 \mathrm{~min}$ & $86 \% \pm 7.7$ at $12: 00$ noon $\pm 20 \mathrm{~min}$ & $16: 15 \mathrm{~h} \pm 23 \mathrm{~min}$ & $37.25 \pm 3.3 \mathrm{~h}$ & A & $70-110^{\circ}$ \\
\hline PK & June & 09:00 a.m. \pm 17 min & $2.4 \mathrm{~h} \pm 31 \mathrm{~min}$ & $79 \% \pm 5.1$ at $11: 15$ a.m. $2.4 \mathrm{~h} \pm 17 \mathrm{~min}$ & $16: 30 \mathrm{~h} \pm 17 \mathrm{~min}$ & $38.55 \pm 3.43 h$ & $A$ & $90-120^{\circ}$ \\
\hline
\end{tabular}

$A$, after anthesis.

The average diameter of the stigma was highest at Panikhar, followed by Tiken Batpora and Katarkhal.

Prior to flower anthesis, the adaxial surfaces of the stigmas remain incurved at an angle of $360^{\circ}$ with respect to the ovary. At anthesis, stigmatic lobes start an upward movement, and on days 3-6, the pollen receptive surface of each lobe comes to lie at $90^{\circ}$ with respect to the ovary. By this time, almost $90 \%$ of the stigmas are pollinated. Once the pollen germination starts, these lobes swell and lose their receptivity. Furthermore, these pollinated stigmatic lobes move upward and come to lie at $180^{\circ}$ with respect to the ovary, subsequently coalescing and forming a funnel-like structure through which pollen tubes move toward the ovary through the style. This movement completes in 67 days of anthesis (Figures 5A-F).

The stigma receptivity was confirmed by pollen germination under a fluorescence microscope and bubbling in $\mathrm{H}_{2} \mathrm{O}_{2}$. The stigmas taken on day 1 of anthesis failed to show results and were thus designated non-receptive. The stigma receptivity was confirmed from days 2 to 8 of anthesis. Populations at Katarkhal show stigma receptivity on the third day of anthesis compared with the populations at Panikhar and Tiken Batpora, where stigma became receptive on the second day. The peak stigma receptivity (seen as the highest number of pollen germination and bubble formation) in Katarkhal was observed on days 6 and 7. In the population of Panikhar, the stigmas attained peak receptivity on days 5 and 6, while the populations at Tiken Batpora showed the highest receptivity on days 4 and 5 . A decline in the stigma receptivity was seen from day 6 , which finally ended on day 8 . The complete pattern of stigma receptivity is explained in Figure 6.

\section{Fertilization}

A large number of pollen grains were found germinating on the stigmatic surface. The pollen tube takes about $2-3 \mathrm{~h}$ to reach the ovary. The stigmas were manually cross- and self-pollinated. 

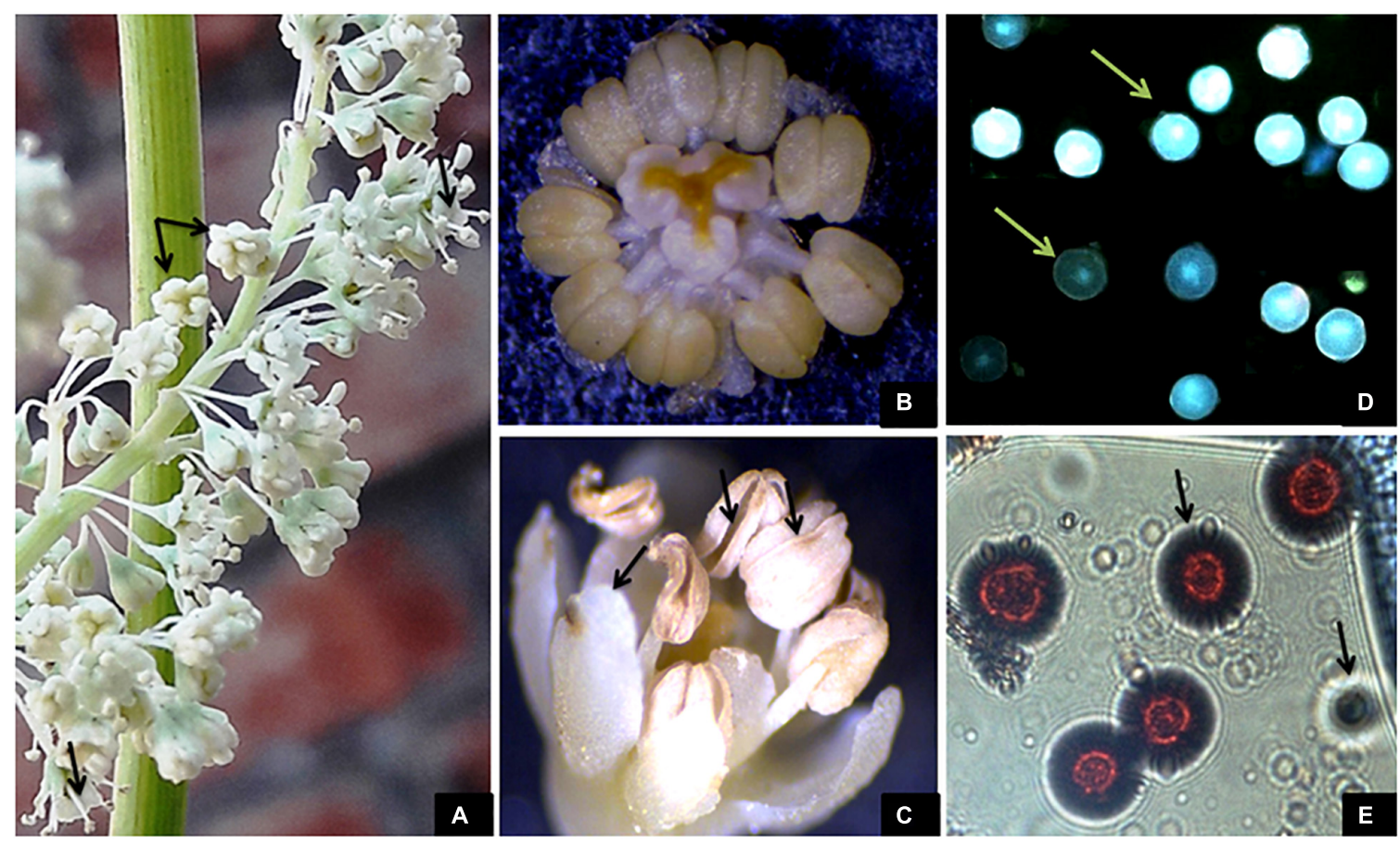

FIGURE 3 | (A) Flower anthesis and outward movement of stamens taking anthers away from the stigma. (B) Hermaphrodite flower with 9 bithecous anthers and incurved stigmas. (C) Post-pollination incurved movement of stamens and petals and anther dehiscence. (D,E) Viable and non-viable pollen grains observed at $40 \times$ and $100 \times$ magnifications.

The pollen tubes of both self- and cross-nature approximately took the same time to reach the ovules. After reaching a certain length, the growth of pollen tubes is blocked inside the style; however, a small number of pollen tubes traverse the style; and finally, a single pollen tube enters the ovule to initiate fertilization (Figures 7A-E).

\section{Fruit Formation and Reproductive Output}

In $R$. webbianum, the fruit formation starts in May and ends in August. On an average, the plants bear 1,346 \pm 303.9, $1,098 \pm 241.4$, and $784 \pm 127.3$ flowers of which $871 \pm 94.6$, $901 \pm 121.4$, and $591 \pm 131.9$ matured into fruits. The percent fruit set was 79.32, 78.62, 75.38\%, and the percent seed set came to 91,87 , and $78 \%$, respectively, at Panikhar, Katarkhal, and Tiken Batpora. A decrease in fruit set on the upper branches of the inflorescence was observed at TBP. One-third of fruits on such branches were either hollow or bore aborted seeds.

\section{Post-fertilization Changes}

The post-fertilization changes were observed through 14-week long period and the entire developmental processes were taken into consideration. Withering of the flowers within the first 2 weeks was recognized as a signal for the failure of fertilization. The fruits matured within a period of $98 \pm 14.4$ days (from pollination up to seed maturation). Manually self-pollinated flowers (autogamy and geitonogamy) showed rapid abscission during the first 5 weeks. The rest of the flowers showed progressive development with less abscission till the complete maturation of the fruits. Open and manually cross-pollinated and bagged flowers show a lesser abscission rate during their early post-fertilization development and a steady abscission rate until last week (Figure 8).

\section{Seed Germination and Seed Survival}

The seeds obtained from different pollination treatments showed a considerable change in their mean weight. The maximum weight was obtained after $78 \mathrm{~h}$ of imbibition, after which a constant weight was obtained for all the samples. After sowing, the seeds started to germinate on the 7 th day and continued up to 16th day. The highest germination was reported for seeds obtained from xenogamy followed by geitonogamy and autogamy in all the populations. The highest mean germination percentage and seedling survival was reported for Tiken Batpora, followed by Panikhar and Katarkhal (Table 5 and Figures 9A-C).

\section{Breeding System}

Different experiments on breeding behavior revealed that it is self-compatible and cross-fertile. None of the emasculated and bagged flowers set fruit, indicating that no apomixis or agamospermy occurs in $R$. webbianum. Manual selfpollination confirms autogamy as well as geitonogamy. The fruit and seed set of cross-pollinated flowers (CP) was significantly higher than that of self-pollinated flowers (SP) (autogamy and geitonogamy). The highest fruit set was observed for open-pollinated flowers [open pollination (OP): flower $(\mathrm{FR})=103$, percent fruit set $(\% \mathrm{FS})=68.66$, percent seed set 

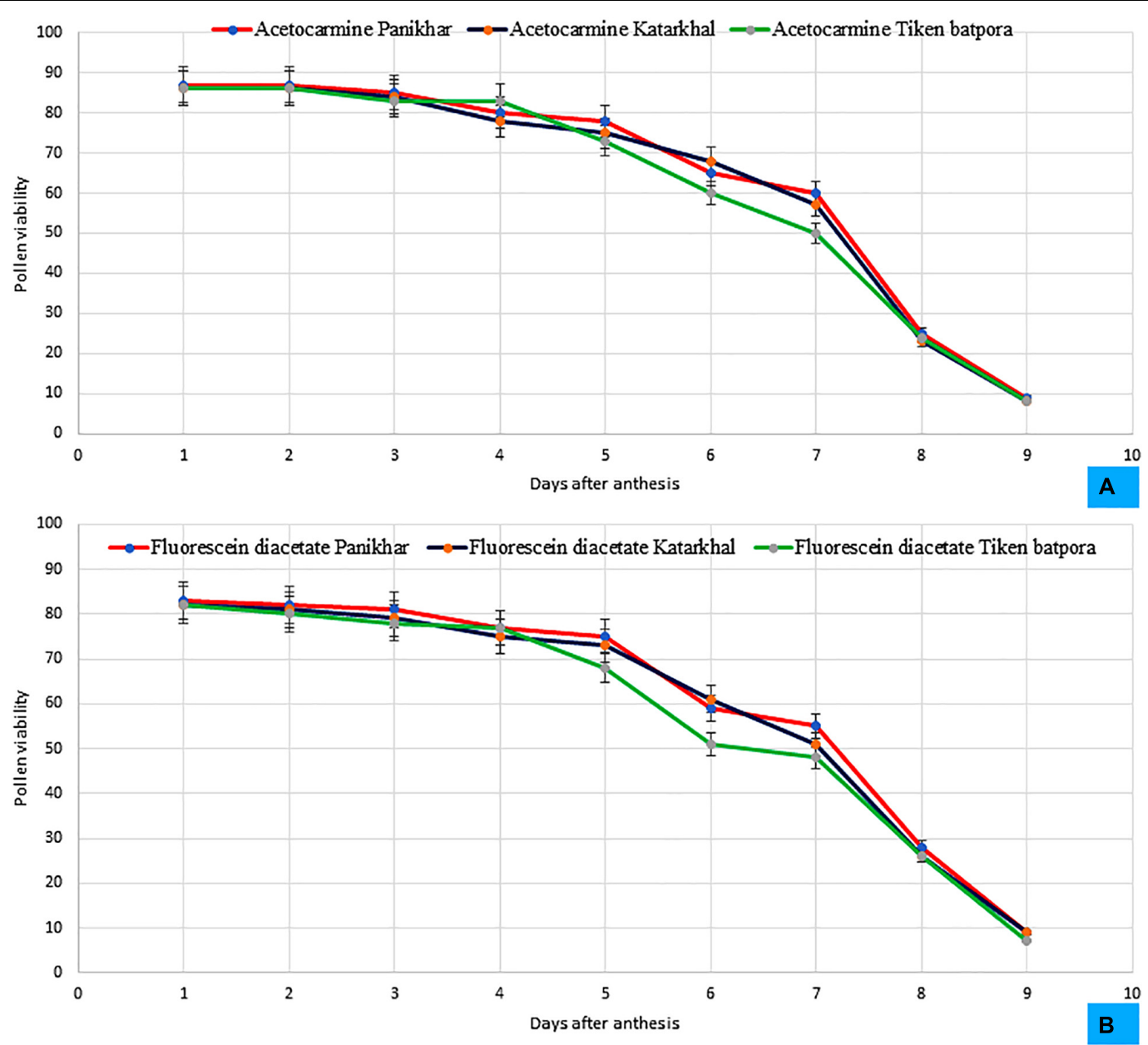

FIGURE 4 | Pattern of the pollen viability at different populations observed in (A) $1 \%$ acetocarmine, (B) Fluorescein diacetate (FDA) (bars represent SD for $n=20$ replicates).

$(\% \mathrm{SS})=86 P<0.001$ - emasculated and manually cross pollinated (EMCP): $\mathrm{FR}=92, \% \mathrm{FS}=61.33, \% \mathrm{SS}=81 \mathrm{P}<0.001]$ compared with self-pollinated flowers [unemasculated flowers bagged (UEB): $\mathrm{FR}=59, \% \mathrm{FS}=39.33, \% \mathrm{SS}=72.8 P<0.001-$ manual geitonogamy $(\mathrm{MG}): \mathrm{FR}=56, \% \mathrm{FS}=37.33, \% \mathrm{SS}=69 \mathrm{P}<0.001$ manual autogamy $(\mathrm{MA}): \mathrm{FR}=52, \% \mathrm{FS}=34.66, \% \mathrm{SS}=63.64$ $P<0.001]$. The reproductive efficacy index as determined for the plant was quite low at 0.71 , which ranged between 0.5 and 0.75 at the $95 \%$ CI. Detailed results of the breeding system are explained in Table 6. The results of the two-way ANOVA indicate that there is a significant effect of treatment on both the fruit and seed development, but the effect of site turned out to be non-significant.

\section{Outcrossing Index, Index of Self-Incompatibility, and Inbreeding Depression}

The outcrossing index of Cruden was maximum, strongly favoring the outcrossing nature of the species. A maximum score of 5 was found for all the populations. The ratio of percent seed set obtained on manual self-: cross-pollination treatment is quite high (0.7) from its threshold level $(\leq 0.2)$, which revealed the self-compatible nature of this plant species. A significant level of inbreeding depression $(P<0.01)$ was reported for self-pollinated fruits. The fruits obtained on xenogamy were heaviest, followed by geitonogamy and autogamy (Table 5).

\section{Pollination Mechanism}

The flowers of $R$. webbianum are both entomo- and anemophilous. The plants are both self-compatible and cross-fertile. Some populations had only a few distantly placed individuals (approximately $100 \mathrm{~m}$ ). Such populations undergo either auto- or geitonogamy through the mediation of strong winds blowing from north to south at Katarkhal (3,474 m.a.s.l.) and from north to the westward at Panikhar (3,227 m.a.s.l.). At Tiken Batpora (1,992 m.a.s.l.), the pollination was facilitated only by insects (entomophily). It was confirmed through a hanging slide experiment that at TBP, no pollen was observed on the hung slides around the plants, whereas the insects collected were laden with conspecific pollen on their body parts. Airborne pollen 

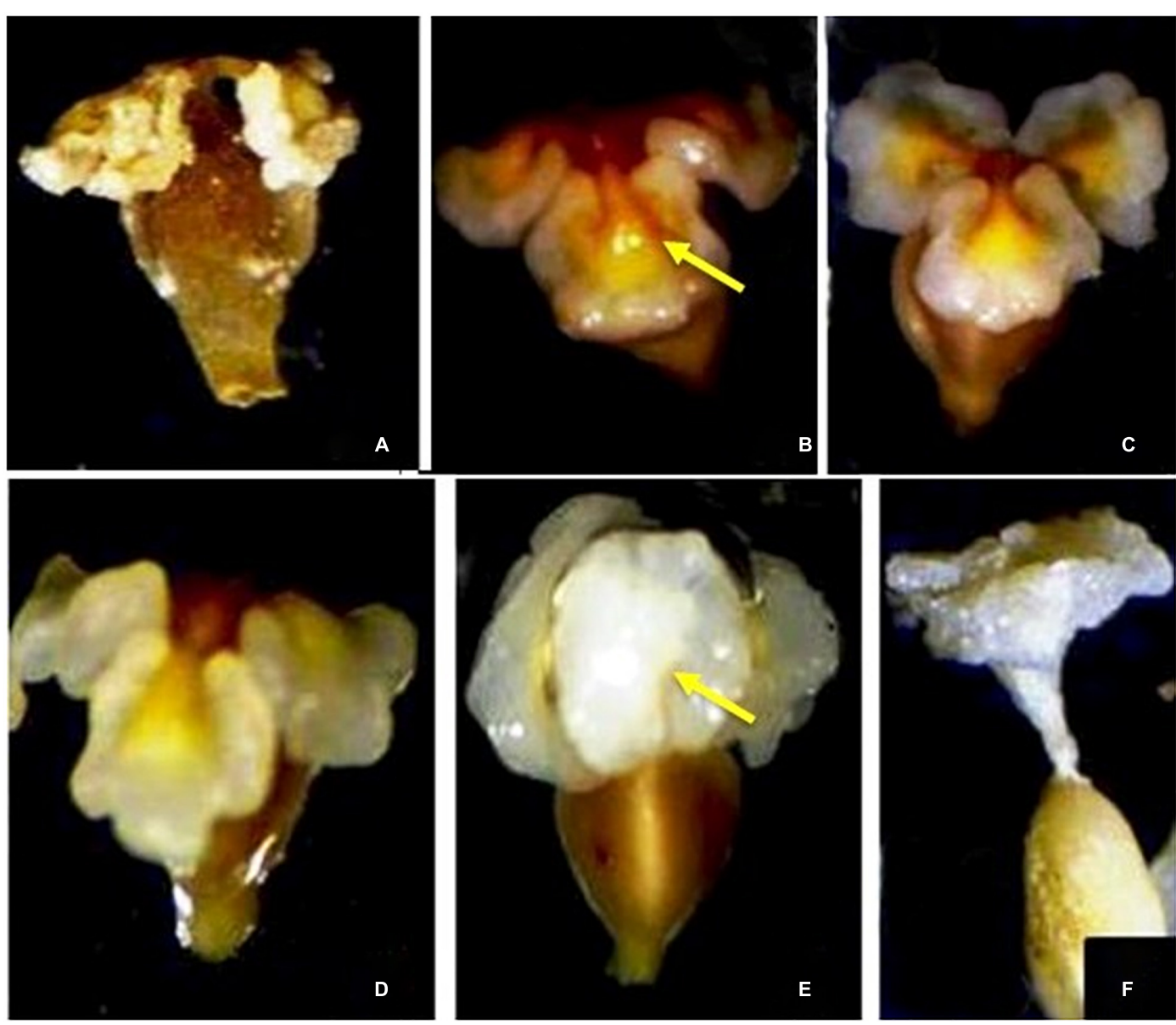

FIGURE 5 | (A-F) Stigma-stylar movement in Rheum webbianum.

that was caught on Meyers albumin smeared on hanging slides confirmed the role of wind in facilitating cross-pollination in the Panikhar and Katarkhal populations. The pollination occurs both during the day as well as at night. Sixty-six of the 100 flowers unbagged during the day matured into fruits, compared with 37 of the 100 flowers that were unbagged only at night.

\section{Insect Visitors and Their Pollination Indices}

A total of 16 different insect visitors were observed, belonging to four orders (Hymenoptera, Diptera, Lepidoptera, and Thysanoptera), nine families, and 11 genera. Hymenoptera was observed as the most dominant order, with 12 insect visitors. Pollinator abundance and richness were highest at Tiken Batpora, followed by Panikhar and Katarkhal. Based on different pollination indices, Apis cerana and Apis mellifera at Tiken Batpora, Bombus lucorum, and Lasioglossum sp. at Katarkhal and Bombus asiaticus, Bombus ferganicus, and Aphelinus sp. at Panikhar were classified as the dominant pollinators. Comparative pollination indices of different pollinators are given in Table 7. Small pollen load was observed on the body parts of Lasioglossum sp., Musa domestica, Vanessa cardui, Xylocopa sp.,
Thrips, and Xylocopa valga and hence were considered inefficient pollinators or robbers. One-way ANOVA showed that there was a significant difference in the pollen load on body parts for different pollinators. Thorax and abdomen showed the highest number of pollen grains followed by wings and head (Table 8).

\section{Pollination Efficiency and Behavior of Pollinators}

The pollination efficiency of the pollinators was evaluated on the basis of pollen load attached to their body parts and its subsequent deposition on the stigma of another flower. The natural pollination efficiency ranged between $39 \pm 21.1$ and $421 \pm 71.90$ pollen grains per stigma, which was enough to fertilize a single ovule in the flower. The compact arrangement of flowers in terminal panicle inflorescences provides a platform to pollinators for easy landing. Depending on the size of the pollinators, landing requires $3-8 \pm 2.1$ flowers. On average, 7 out of 10 pollinators landed in the middle portion of the inflorescence from which they were seen either moving upward or downward. A single visit of a pollinator resulted in gnawing of 3-12 \pm 2.2 flowers. The average time spent by a pollinator for doing so ranged between $3-42 \pm 2.2 \mathrm{~s}$. 


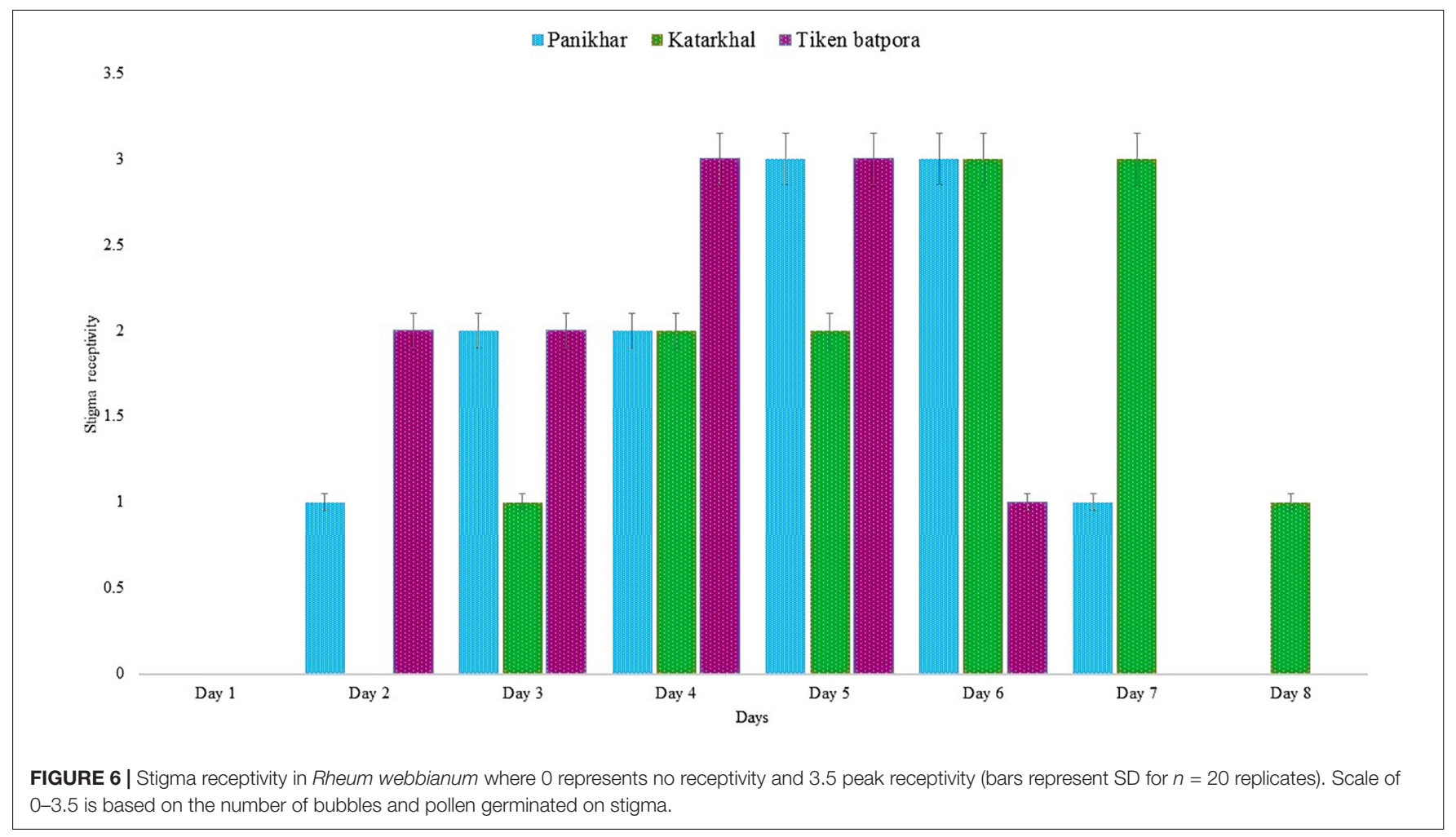

While foraging nectar, the pollinators received pollen from dehisced anthers and subsequently on a visit to another flower (from the same or a different plant), such pollen was transferred to the stigma. The elevated position of anthers at dehiscence results in deposition of the highest pollen load on the cephalothoraxic region, followed by the abdomen, legs, and wings of such insects. The pollen attached to the proboscis of some pollinators leads to pollination of different flowers. Apis spp. and Bombus spp. were the pollinators for more behavioral observations. These were the most frequent visitors, moving very quickly between the plants in the population and among the branches of inflorescence. Apis spp. crawled over the flowers and inserted their proboscises into the base of the ovary. On some of the occasions, these pollinators were seen moving up the inflorescences first and then down, visiting previously skipped flowers. Such pollinators never revisited the flowers that were gnawed during the particular visits to an inflorescence. While collecting the nectar, the lateral and ventral sides of the abdomen of such pollinators get brushed against anthers, resulting in deposition of a copious amount of pollen grains on their body parts. Bumblebees were seen landing directly on the stigma of the flower. While making an effort to lick the nectar, their posterior body parts touch the dehisced anthers. Eupeodes corollae, Aphidius sp., and Aphelinus sp. keep their abdomens elevated and inclined while resting on flower tepals. Lasioglossum sp., Musa domestica, Allograpta sp., Vanessa cardui, Xylocopa sp., and Xylocopa valga fly over and around the inflorescences before a brief stay on the flowers, stretching their mouthparts through petal gaps to reach the nectary located at the base of the perianth. Stomoxy sp., and Vespula sp., crawled in a circular fashion around the margins of the stigmatic lobes before landing on the adaxial surface of the stigma.

\section{Insect Visitation vis-a-vis Environmental Factors}

External environmental factors, such as wind, clouds, rain, and temperature, showed a significant influence on the visiting behavior of insect pollinators. However, ants, aphids, thrips, beetles, and bugs were the least affected. On normal sunny days, the insects were observed visiting early in the morning and continued throughout the day. The frequency of insect visitation increased with increasing temperature and illumination. The peak insect visitation was reported between 12:00 and 14:00 h, which declined thereafter. The highest visitation frequency of pollinators was reported on bright sunny days, which declined because of clouds, wind, and rain (Figure 10).

\section{DISCUSSION}

\section{Floral and Reproductive Phenology}

The phenology of a plant species not only deals with the vegetative and reproductive phases corresponding to the climate and seasonal changes of a particular area but also determines the degree of reproductive synchrony with other plant species (Rathcke and Lacey, 1985). A key tool for the plant management is to have the information on floral biology and estimation of reproductivity and regeneration (Mulik and Bhosale, 1989). During the present study on $R$. webbianum, it was observed that phenophases of the plant species showed a significant variation 


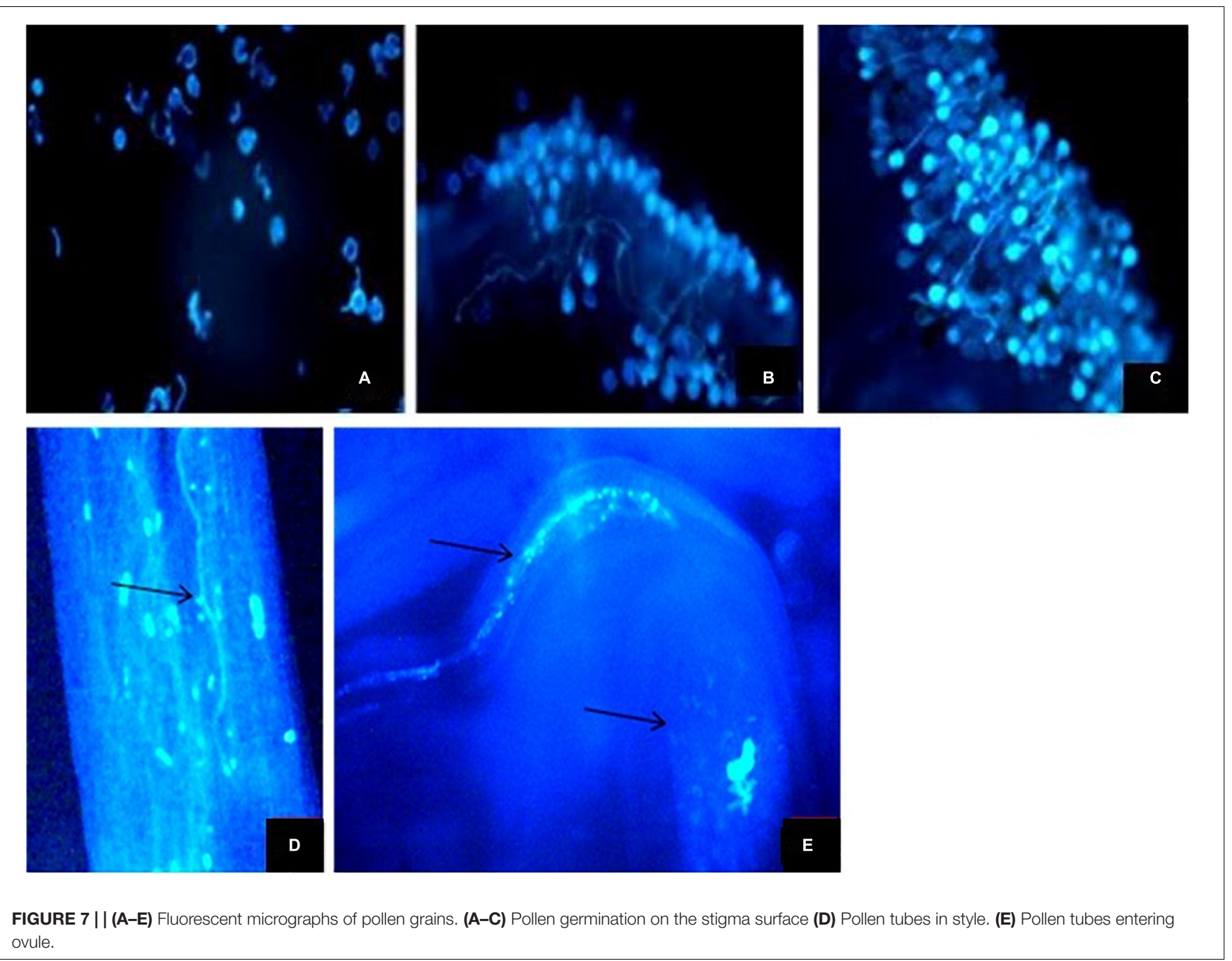

across the selected populations. Elevated temperatures accelerate plant development processes and as such advance the different phenophases (Gordo and Sanz, 2010; Bjorkman et al., 2015; Moore and Lauenroth, 2017; Dorji et al., 2020). At lower altitudes, $R$. webbianum showed early germination, which could be attributed to the difference in temperature as well as available moisture as reported by workers in other plant species (Tao et al., 2008; Julien and Sobrino, 2009). Populations at Katarkhal showed lowest leaf size and number, length and width of the petiole, length and thickness of the rhizome, and inflorescence size and width. These results can be related to the findings of Siddique et al. (1997), Bresson et al. (2011), and Yaqoob and Nawchoo (2015) who also reported a reduction in the phenological characters of plants with an increase in elevations. According to Korner (2003) and Baret et al. (2004), reduction in the morphometric characters is the adaptation of alpine plants that may result due to slow growth, which allows the alpine plants to use the resources more efficiently. Smaller inflorescences at higher altitudes help plants to avoid the detrimental consequences of strong and gusty winds (Korner and Cochrane, 1983; Yaqoob and Nawchoo, 2015).

\section{Flower Anthesis}

Anthesis is a vital event in the morphogenesis and overall development of the flower (Smitha and Thondaiman, 2016; Kumari et al., 2020). The bud dormancy of many plant species is broken when forced to experience high temperatures (Rohde and Bhalerao, 2007). With the increase in temperature, the flower anthesis hastened in R. webbianum, as cracks on flower buds appeared with early sunshine, resulting in the separation of perianth lobes. These findings are supported by the results of De Hertogh and Le Nard (1993) and Noy-Porat et al. (2009) who reported the favorable role of high temperature in flower anthesis in Narcissus and Tulipa inhabiting temperate to subalpine conditions.

\section{Pollen Biology, Stigma Receptivity, and Pollen Pistil Interaction}

The pollen viability and the efficiency of pollen transfer are important steps indicating the reproductive success of a plant species (Khan et al., 2021). A reduction in pollen viability is a common trait in angiosperms growing under changing weather 


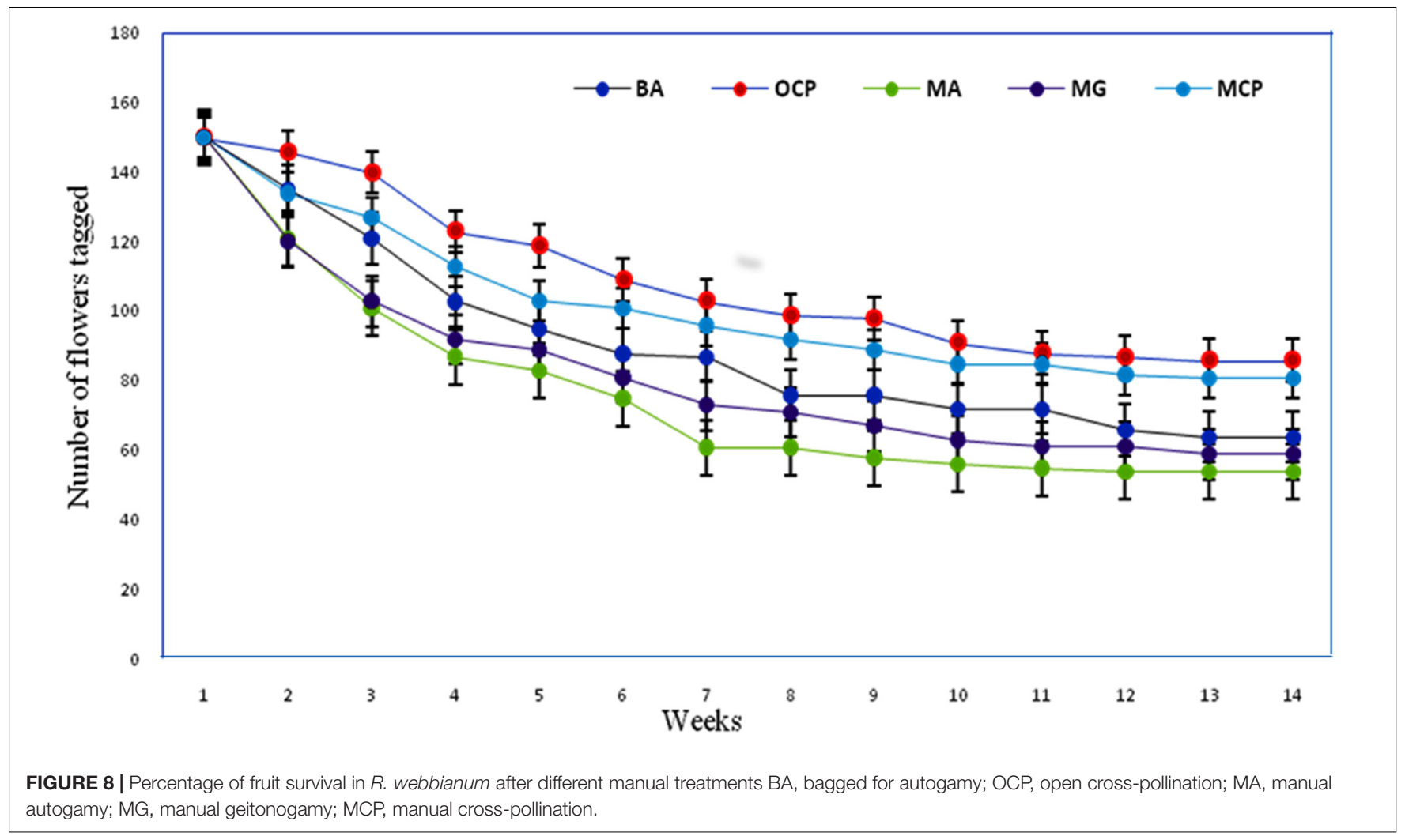

conditions (Porch and Jahn, 2001; Fang et al., 2010). A slight decrease in the pollen viability at populations of Katarkhal as compared with that of Panikhar can be attributed to the climatic stress induced due to changing weather conditions during the reproductive phase of $R$. webbianum. Pollen viability declined with the age of flower and such findings are in line with the studies of Mercado et al. (1994) and Rodriguez-Riano and Dafni (2007), who reported a steady decline in pollen viability with the aging of flowers.

For the successful initiation of pollen pistil interaction, pollen viability and stigma receptivity are important parameters (Verma et al., 2004; Khajuria et al., 2011). Stigma receptivity can be useful in determining the optimum time to perform manual pollination besides being helpful in describing pollen/stigma incompatibility (Dafni, 1992). Details of the stigma receptivity in the plant species are described by a limited number of studies (Shivanna, 2003), as there are no satisfactory precise methods to determine the stigma receptivity. The presence of certain enzymes, such as acid phosphatases, peroxidases, and esterases, mark the receptivity of stigmas (Dafni, 1992; Dafni and Maués, 1998) but this may not be true for all the cases, as in some species, these enzymes are secreted before the stigmas get receptive (Shivanna and Sastri, 1981). In these cases, manual pollination treatments could only be a definite method to determine the stigma receptivity (Shivanna, 2003). In case of $R$. webbianum, the pattern of pollen germination on stigma and bubble formation in $\mathrm{H}_{2} \mathrm{O}_{2}$ showed similar results. Moreover, extended stigma receptivity was seen in $R$. webbianum, which assures fertilization and reproductive success (Castro et al., 2008). This time frame appears to be an approach to ensure reproductive output in this species growing under extreme climatic conditions.

\section{Dichogamy and Stigma Movement, a Contrivance for Cross-Pollination}

Dichogamy is believed to have progressed to contribute toward outbreeding that limits pollen and stigma interference in the same flower or within the plant (Bertin and Newman, 1993; Barrett, 2002). Delayed selfing through stylar movement (Verma et al., 2004; Ruan et al., 2009) and flexistyly (Li et al., 2001) are some mechanisms that promote outcrossing in some plant species. Incurved stigmas at anthesis in $R$. webbianum seem to limit the chances of self-pollination in this species. Dichogamy (protandry), reverse herkogamy, and stylar-stigmatic movements strongly promote outcrossing in this species. Crosspollination not only maintains certain levels of heterozygosity in the populations but also prevents certain levels of inbreeding depression (Hu et al., 2011; Li et al., 2019).

\section{Breeding System}

The breeding system plays an important role in the generation of variation and hence in the evolution of a species (Grant, 1971). The pollen-ovule ratio $(\mathrm{P} / \mathrm{O})$ is the best indicator of a species' breeding pattern (Gallardo et al., 1994). The greater pollen ovule ratio in $R$. webbianum indicates that xenogamy and facultative xenogamy are the most operative modes of pollination exhibited by this plant species. The same was confirmed by undertaking bagging experiments. R. webbianum practiced 
TABLE 5 | Seed germination and seedling survival in Rheum webbianum $(n=25)$.

\begin{tabular}{|c|c|c|c|c|c|c|c|c|c|c|c|c|}
\hline \multirow[t]{2}{*}{ Treatment } & \multicolumn{3}{|c|}{ Dry weight (milligrams) } & \multicolumn{3}{|c|}{$\begin{array}{l}\text { Maximum weight after } \\
\text { imbibition (milligrams) }\end{array}$} & \multicolumn{3}{|c|}{ Germination (percentage) } & \multicolumn{3}{|c|}{$\begin{array}{l}\text { Seedling survival } \\
\text { (percentage) }\end{array}$} \\
\hline & PK & KS & TBP & PK & KS & TBP & PK & KS & TBP & PK & KS & TBP \\
\hline Xenogamy & $32 \pm 0.29$ & $29 \pm 0.23$ & $35 \pm 0.48$ & $75 \pm 5.5$ & $71 \pm 4.4$ & $78 \pm 6.1$ & $94 \pm 8.4$ & $91 \pm 6.6$ & $95 \pm 4$ & $82 \pm 3$ & $79 \pm 3$ & $84 \pm 5.2$ \\
\hline Geitonogamy & $29 \pm 0.25$ & $28 \pm 0.22$ & $31 \pm 0.54$ & $62 \pm 4.7$ & $59 \pm 4.1$ & $66 \pm 5.5$ & $90 \pm 7.8$ & $89 \pm 4.3$ & $92 \pm 4$ & $79 \pm 4$ & $75 \pm 3$ & $81 \pm 4.9$ \\
\hline Autogamy & $27 \pm 0.25$ & $25 \pm 0.18$ & $28 \pm 0.51$ & $65 \pm 4.9$ & $61 \pm 4.6$ & $69 \pm 4.9$ & $88 \pm 6$ & $88 \pm 4.4$ & $89 \pm 3.5$ & $76 \pm 4$ & $72 \pm 3$ & $78 \pm 4.2$ \\
\hline
\end{tabular}

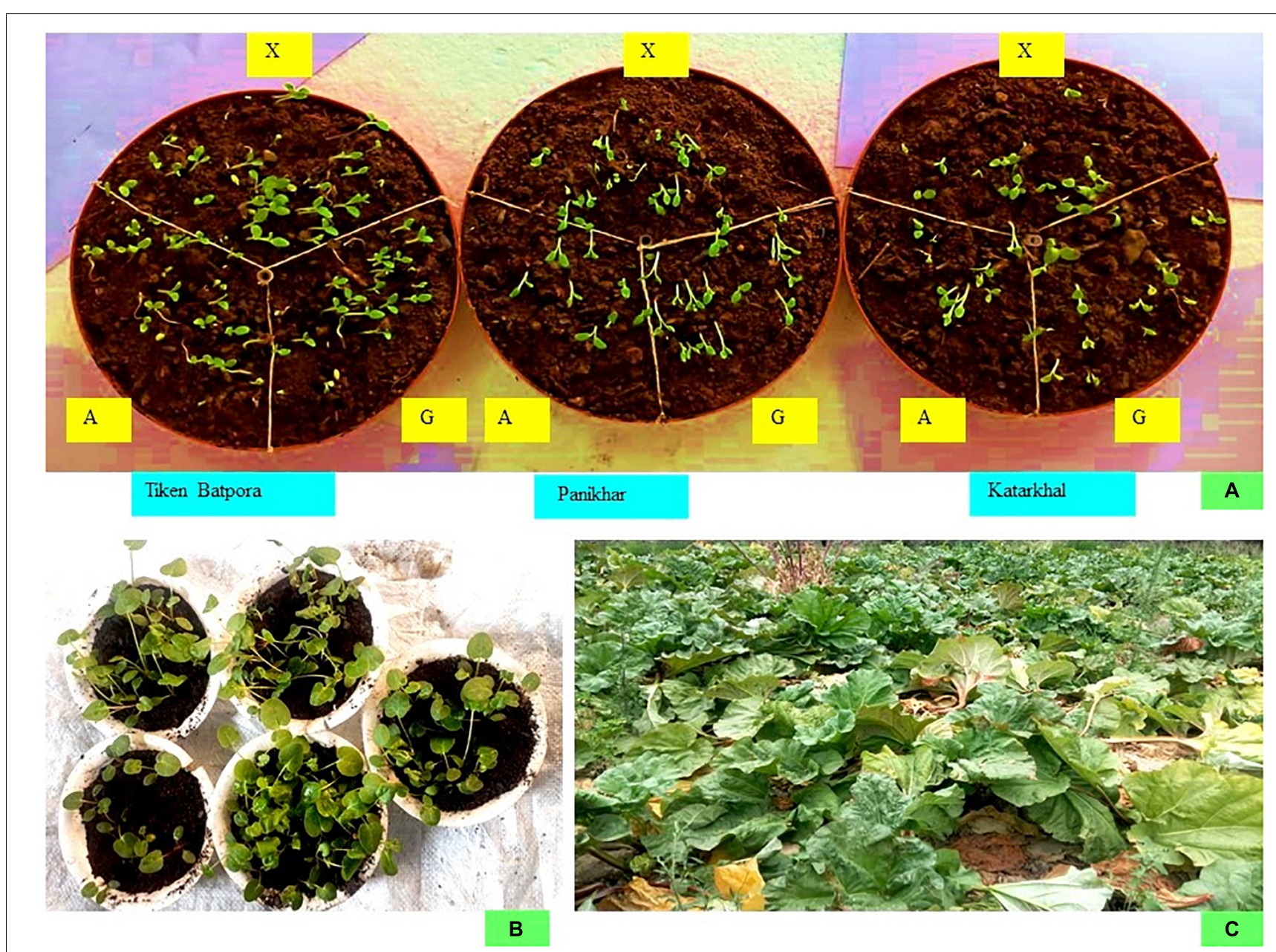

FIGURE 9 | Seed germination and seedling transplantation. (A) Seed germination results of the seeds obtained from manual treatments X, xenogamy; G, geitonogamy; A, autogamy. (B) Root hardening. (C) Transplanting the plants into field conditions.

facultative xenogamy under pollinator limiting conditions. This strategy of mixed mating appears to be a survival approach by R. webbianum under extreme climatic conditions. However, its stigmatic movement effectively prevents self-pollination and acts as a contrivance for cross-pollination indicating that the breeding system of $R$. webbianum is in the process of evolving from selfing to outcrossing. This finding is supported by the results of Ganie et al. (2017), who also reported a similar mechanism in $R$. webbianum. Although cross-pollination contributes to heterozygosity, self-pollination under limiting conditions helps the plant to set seeds and to survive challenging environmental conditions. The same kind of observations has been reported by Huang et al. (2006) and Khajuria (2013) for other plant species, in which plants shift to self-pollination mode under limiting conditions.

\section{Pollination Ecology}

The mutualism between the plants and the pollinators depends on the exchange of food and efficient vectoring of sexual reproduction for plants. During the course of evolution, these interactions have been modified by a variety of factors, which include both biotic as well as abiotic constraints. While 
TABLE 6 | Seed set in Rheum webbianum following different treatments.

\begin{tabular}{|c|c|c|c|c|c|c|}
\hline Treatments & Plants & Flowers & Fruits & $\begin{array}{c}\% \text { Fruit } \\
\text { set }\end{array}$ & Seeds & $\begin{array}{c}\% \text { seed } \\
\text { set }\end{array}$ \\
\hline $\begin{array}{l}\text { Emasculated and } \\
\text { bagged (apomixis) }\end{array}$ & 6 & $150 \pm 5.77$ & 0 & 0 & 0 & 0 \\
\hline $\begin{array}{l}\text { Un emasculated } \\
\text { flowers bagged } \\
\text { (bud conditions) }\end{array}$ & 6 & $150 \pm 13.81$ & 59 & $39.33 \%$ & 43 & 72.8 \\
\hline Manual autogamy & 6 & $150 \pm 5.77$ & 52 & $34.66 \%$ & 33 & 63.64 \\
\hline Manual getinogamy & 6 & $150 \pm 5.37$ & 56 & $37.33 \%$ & 39 & 69.64 \\
\hline Open pollination & 6 & $150 \pm 5.52$ & 103 & $68.66 \%$ & 86 & 86 \\
\hline $\begin{array}{l}\text { Emasculated and } \\
\text { manually cross } \\
\text { pollinated }\end{array}$ & 6 & $150 \pm 5.16$ & 92 & $61.33 \%$ & 81 & 81 \\
\hline
\end{tabular}

a large group of pollinators is generalists (Hingston and McQuilan, 2000; Ollerton, 2014), there are some specialists that have evolved throughout the course of evolutionary history (Proctor et al., 1996; Endress and Bruyns, 2000). Bumblebees are believed to have coevolved with the climatic conditions at alpine zones and can happily pollinate the plants growing up to the altitude of 9,000 m.a.s.l. (Dillon and Dudley, 2014). Preferentially, bumblebees constitute the group of specialist pollinators for $R$. webbianum, which is supported by various pollination indices. This analysis is equally supported by the findings of Pradervand et al. (2014), who also found such pollinator groups to be dominant in the other alpine regions.

The floral morphology is of greater importance, as it determines the pollination behavior of different plant species (Vikas, 2011; Yamasaki and Sakai, 2013). Leafless terminal inflorescences, small perianth, exposed stigmatic surface, raised anthers, and lightweight pollen are anemophilous floral features in $R$. webbianum. Features like dichogamy (protandry), reverse herkogamy, incurved stigmas, delicate fragrance, nectar availability, and dense and showy inflorescences favor insect pollination. The importance of such traits for attracting pollinators has also been reported in other plant species (Dafni, 1992; Mayer et al., 2011; Yamasaki and Sakai, 2013). The data generated in the case of $R$. webbianum prompted us to design an ex situ conservation strategy for the management of this important but threatened high-value medicinal plant.

\section{Conservation Strategy}

The present study on reproductive biology featuring phenology, floral traits, pollination, and breeding behavior has provided mechanistic insights into the life history pattern of $R$. webbianum, a vulnerable medicinal plant of North-West Himalaya. The species faces anthropogenic stress in nature and disjunct population distribution makes it more susceptible to exploitation. Since the species depends upon specialist pollinators, any climatic change affecting the pollinator availability and abundance will be affecting its survival too. Low seed germinability under in situ conditions is also a cause of concern. On the basis of the information generated so, an effective conservation program for the species will be comprised of both in situ and ex situ approaches. Since the species shows habitat specificity, all its habitats need to be protected. The exploitation of the species needs to be stopped through the intervention of forest department as well as other law enforcing agencies. The in situ populations need to be protected from grazing and trampling. It would save the already sparse populations from damage and further destruction. Ex situ conservation and seed collection should then be carried out to provide for its future recovery. Restoration of natural populations using ex situ raised seedlings

TABLE 7 | Pollination indices of different visitors across different study areas.

\begin{tabular}{|c|c|c|c|c|}
\hline Site & Pollinator & Foraging behavior & Insect visiting efficiency & Index of visitation rate \\
\hline \multirow[t]{8}{*}{ TBP } & Apis cerana & $5.7 \pm 0.91$ & $0.159 \pm 0.07$ & $189 \pm 23.3$ \\
\hline & Apis mellifera & $4.94 \pm 0.79$ & $0.113 \pm 0.09$ & $204 \pm 17.7$ \\
\hline & Allograpta sp. & $2.7 \pm 0.43$ & $0.068 \pm 0.03$ & $35.9 \pm 8.5$ \\
\hline & Musa domestica & $1.17 \pm 0.37$ & $0.02 \pm 0.01$ & $24.85 \pm 7.7$ \\
\hline & Camponotus sp. & $8.19 \pm 1.15$ & $0.15 \pm 0.11$ & $478.9 \pm 76.16$ \\
\hline & Eupeodes corollae & $3.61 \pm 1.19$ & $0.143 \pm 0.11$ & $47.07 \pm 12.02$ \\
\hline & Vanessa cardui & $1.17 \pm 0.39$ & $0.09 \pm 0.068$ & $7.71 \pm 2.2$ \\
\hline & Vespula sp. & $0.73 \pm 0.22$ & $0.05 \pm 0.026$ & $5 \pm 4.5$ \\
\hline \multirow[t]{6}{*}{ KS } & Lasioglossum sp. & $4.17 \pm 1.19$ & $0.109 \pm 0.09$ & $27.79 \pm 4.4$ \\
\hline & Bombus lucorum & $5.17 \pm 2.2$ & $0.227 \pm 0.09$ & $204 \pm 22.72$ \\
\hline & Eupeodes corollae & $5.05 \pm 0.91$ & $0.339 \pm 0.12$ & $317 \pm 17.7$ \\
\hline & Xylocopa valga & $0.55 \pm 0.21$ & $0.073 \pm 0.021$ & $6.6 \pm 2.54$ \\
\hline & Eupeodes corollae & $1.23 \pm 0.29$ & $0.03 \pm 0.009$ & $10.17 \pm 3.3$ \\
\hline & Musa domestica & $1.59 \pm 0.12$ & $0.05 \pm 0.01$ & $36.06 \pm 7.72$ \\
\hline \multirow[t]{6}{*}{ PK } & Aphelinus sp. & $4.97 \pm 0.98$ & $0.227 \pm 0.063$ & $187 \pm 13.3$ \\
\hline & Aphidius sp. & $4.12 \pm 0.92$ & $0.161 \pm 0.097$ & $89 \pm 9.9$ \\
\hline & Bombus asiaticus & $4.97 \pm 0.28$ & $0.193 \pm 0.11$ & $119 \pm 15.5$ \\
\hline & Bombus ferganicus & $7.73 \pm 2.28$ & $0.229 \pm 0.085$ & $172 \pm 17.34$ \\
\hline & Bombus melanurus & $6.9 \pm 2.16$ & $0.277 \pm 0.067$ & $138 \pm 26.9$ \\
\hline & Xylocopa sp. & $1.05 \pm 0.51$ & $0.093 \pm 0.05$ & $14.4 \pm 4.54$ \\
\hline
\end{tabular}


TABLE 8 | Pollen load on different body parts of insect visitors.

\begin{tabular}{|c|c|c|c|c|c|c|c|c|}
\hline \multirow[t]{2}{*}{ Insect visitor } & \multirow[t]{2}{*}{ Order } & \multirow[t]{2}{*}{ Family } & \multirow[t]{2}{*}{ E.P } & \multicolumn{5}{|c|}{ Pollen load } \\
\hline & & & & Head & Thorax & Abdomen & Wings & Legs \\
\hline Aphelinus sp. & Hymenoptera & Aphelinidae & M & $11 \pm 5.5$ & $247 \pm 121.14$ & $119 \pm 79.83$ & $27 \pm 14.09$ & $15 \pm 4.4$ \\
\hline Aphidius sp. & Hymenoptera & Braconidae & M & $9.9 \pm 5.8$ & $217.7 \pm 137.7$ & $161.09 \pm 92.09$ & $41.69 \pm 21.01$ & $17 \pm 7.9$ \\
\hline Apis cerana & Hymenoptera & Apidae & $\mathrm{H}$ & $121 \pm 47.21$ & $479.3 \pm 192.9$ & $224.1 \pm 132.7$ & $92 \pm 37.91$ & $21 \pm 11.9$ \\
\hline Apis mellifera & Hymenoptera & Apidae & $\mathrm{H}$ & $127 \pm 55.05$ & $512 \pm 292.5$ & $314 \pm 142$ & $63 \pm 23.09$ & $29 \pm 17.07$ \\
\hline Bombus asiaticus & Hymenoptera & Apidae & $\mathrm{H}$ & $87.5 \pm 23.9$ & $313.7 \pm 107$ & $198 \pm 72.07$ & $58.09 \pm 22.19$ & $37.17 \pm 13.9$ \\
\hline Bombus ferganicus & Hymenoptera & Apidae & $\mathrm{H}$ & $83 \pm 27.07$ & $273.8 \pm 47.8$ & $149 \pm 23.06$ & $41 \pm 13.01$ & $39.09 \pm 13$ \\
\hline Bombu s lucorum & Hymenoptera & Apidae & $\mathrm{H}$ & $53.8 \pm 13.9$ & $267.7 \pm 71.9$ & $211 \pm 51.81$ & $53.3 \pm 9.9$ & $27.07 \pm 11.3$ \\
\hline Bombus melanurus & Hymenoptera & Apidae & $\mathrm{H}$ & $83 \pm 21.09$ & $277.9 \pm 39.9$ & $109.9 \pm 17.7$ & $32 \pm 9$ & $17 \pm 8.3$ \\
\hline Camponotus sp. & Hymenoptera & Formicidae & $\mathrm{H}$ & $27 \pm 9.09$ & $72.7 \pm 21.9$ & $51.13 \pm 12.02$ & $14.7 \pm 5$ & $9.5 \pm 7.7$ \\
\hline Eupeodes corollae & Diptera & Syrphidae & M & $19 \pm 5.9$ & $47.09 \pm 13.03$ & $29.12 \pm 6.6$ & - & - \\
\hline Lasioglossum sp. & Hymenoptera & Halictidae & M & $7.07 \pm 3.9$ & $31.17 \pm 10.9$ & $39.89 \pm 12.02$ & - & - \\
\hline Musa domestica & Diptera & Muscidae & $\mathrm{L}$ & - & $19 \pm 4.7$ & $17.07 \pm 4.3$ & - & $13 \pm 3$ \\
\hline Vanessa cardui & Lepidoptera & Nymphalidae & $\mathrm{L}$ & - & - & $19.09 \pm 4.2$ & - & $21.09 \pm 11$ \\
\hline Xylocopa sp. & Hymenoptera & Apidae & $\mathrm{L}$ & - & $47 \pm 17.07$ & $14 \pm 5.1$ & - & - \\
\hline Xylocopa valga & Hymenoptera & Apidae & $\mathrm{L}$ & - & $53.8 \pm 16.06$ & $23 \pm 6$ & - & - \\
\hline Thrips & Thysanoptera & Thripidae & $\mathrm{L}$ & $16.06 \pm 4.9$ & $23 \pm 5.9$ & 21.09 & $7.14 \pm 2.21$ & $5.5 \pm 2.2$ \\
\hline
\end{tabular}

EP, Effective pollinator; H, High; L, Low; M, Moderate; Ab, Abdomen.

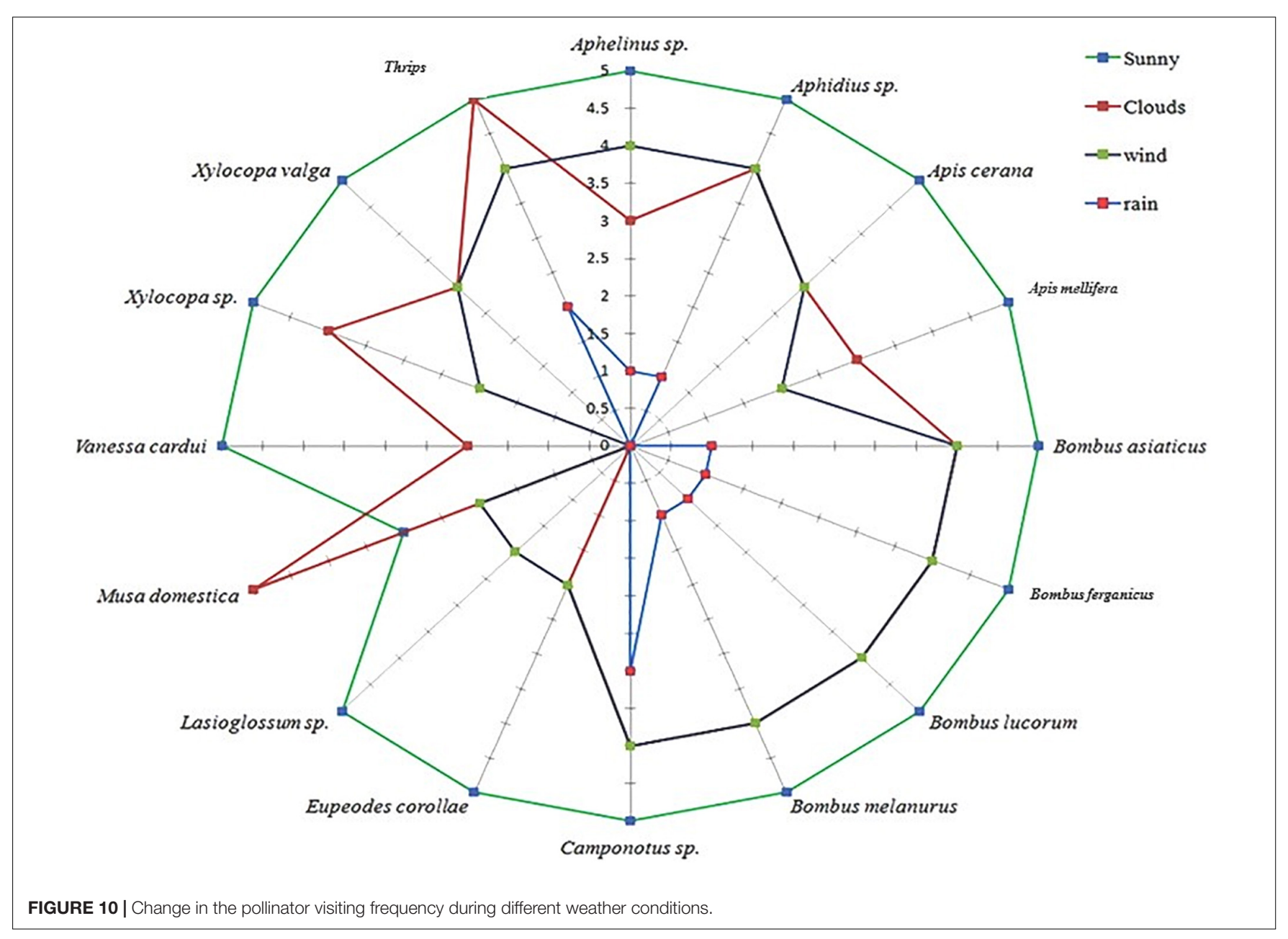


and saplings will also be contributing toward the recovery of this very important medicinal plant.

\section{CONCLUSION}

The present study revealed that $R$. webbianum grows in disjunct populations at different elevations and a wide range of habitats in Kashmir Himalaya. The species was found to inhabit dry and exposed mountain peaks, moist and bushy habitats, and plains with loose textured soil. Variability in the morphological traits of this species was observed across different altitudinal gradients, which reflect its phenotypic plasticity and adaptability under different climatic conditions. The plant bears hermaphrodite, dichogamous flowers exhibiting reverse herkogamy and stylar-stigmatic movements to promote outcrossing. It is both self-compatible as well as cross-fertile and ambophilous. The dominance of Hymenopteran pollinators at all the study sites indicates toward the role of specific pollinators in pollination and its reproduction. The species practice mixed mating but manual pollination experiments point toward its outbreeding nature. The information generated thereof reveals that the species exploit both phenotypic as well as reproductive plasticity to survive under limiting and stressful conditions of nature. The information generated so is of great significance and will go a long way in designing the effective strategies for its cultivation, conservation, and sustainable use.

\section{REFERENCES}

Abe, I., Seki, T., Noguchi, H., and Kashwada, Y. (2000). Galloyl esters from rhubarb are potential inhibitors of squaleene epoxidase, a key enzyme in cholestrol biosynthesis. Planta Med. 66, 753-756. doi: 10.1055/s-2000-9781

Agarwal, S. K., Singh, S. S., and Lakshmi, V. (2001). Chemistry and Pharmacology of Rhubarb (Rheum species)- A review. J. Scient. Ind. Res. 60, 1-9.

Anderson, G. J., Johonson, S. D., Neal, P. R., and Bernardello, G. (2002). Reproductive biology and plant systematics: the growth of symbiotic association. Taxon 51, 637-653. doi: 10.2307/3647326

Ashman, T. L. (2003). Constraints on the evolution of males and sexual dimorphism: field estimates of genetic architecture of reproductive traits in three populations of gynodioecious Fragaria virginiana. Evolution 57, 20122025. doi: 10.1111/j.0014-3820.2003.tb00381.x

Baig, B. A., Ramamoorthy, D., and Wani, B. A. (2014). Population status and conservation prioritization of some threatened medicinal plants of Kashmir Himalaya. Int. J. Appl. Biol. Pharm. Technol. 4, 21-29.

Bareke, T. (2018). Biology of seed development and germination physiology. $A d v$. Plants Agric. Res. 8, 336-346. doi: 10.15406/apar.2018.08.00335

Baret, S., Maurice, S., Le Bourgeois, T., and Strasberg, D. (2004). Altitudinal variation in fertility and vegetative growth in the invasive plant Rubus alceifolius (Rosaceae), on Reunion Island. Plant Ecol. 172, 265-273. doi: 10.1023/B:VEGE. 0000026345.67250.d2

Barman, C., Singh, V. C., Das, S., and Tandon, R. (2018). Floral contrivances and specialized pollination mechanism confer strong influence to elicit mixedmating in Wrightia tomentosa (Apocynaceae). Plant Biol. 20, 546-554. doi: $10.1111 / \mathrm{plb} .12690$

Barrett, S. C. H. (2002). The evolution of plant sexual diversity. Nat. Genet. 3, 274-284. doi: 10.1038/nrg776

Becker, U., Colling, G., Dostal, P., Jakobsson, A., and Matthies, D. (2006). Local adaptation in the monocarpic perennial Carlina vulgaris at different spatial scales across Europe. Oecologia 150, 506-518. doi: 10.1007/s00442-006-0534-9

\section{DATA AVAILABILITY STATEMENT}

The original contributions presented in the study are included in the article/supplementary material, further inquiries can be directed to the corresponding author/s.

\section{AUTHOR CONTRIBUTIONS}

SV contributed to conceptualization, validation, investigation, data curation, visualization, and supervision. IW and SV contributed to methodology, formal analysis, and writing original draft. IW and PA contributed to software. SV and PA contributed to resources and project administration. SV, IW, and PA contributed to writing, reviewing, and editing. HE-S and $\mathrm{MH}$ contributed to funding acquisition. All authors have read and agreed to the published version of the manuscript.

\section{ACKNOWLEDGMENTS}

We would like to extend our sincere appreciation to the Head Department of Botany for providing the necessary facilities to carry out the research work. We are grateful to DBT, Govt. of India for funding this research work under the Research Grant No. BT/Env/01/2010. We would like to extend our sincere appreciation to the Researchers Support Project No. (RSP2021/19), King Saud University, Riyadh, Saudi Arabia.

Bentos, T. V., Rita, C. G., Mesquita, G., and Williamson, B. (2008). Reproductive Phenology of Central Amazon Pioneer Trees. Trop. Conserv. Sci. 1, 186-203. doi: $10.1177 / 194008290800100303$

Bertin, R. I., and Newman, C. N. (1993). Dichogamy in angiosperms. Bot. Rev. 59, 112-150. doi: 10.1007/BF02856676

Bjorkman, A. D., Elmendorf, S. C., Beamish, A. L., Vellend, M., and Henry, G. H. R. (2015). Contrasting effects of warming and increased snowfall on Arctic tundra plant phenology over the past two decades Glob. Chang. Biol. 21, 4651-4661. doi: $10.1111 /$ gcb. 13051

Brauner, S., and Gottlieb, L. D. (1987). A self-compatible plant of Stephanomeria exigua subsp. coronaria (Asteraceae) and its relevance to the origin of its selfpollinating derivative S. malheurensis. Syst. Bot. 12, 299-304. doi: 10.2307/ 2419325

Bresson, C. C., Vitasse, Y., Kremer, A., and Delzon, S. (2011). To what extent is altitudinal variation of functional traits driven by genetic adaptation in European oak and beech? Tree Physiol. 31, 1164-1174. doi: 10.1093/treephys/ tpr084

CAMP (2003). Conservation Assessment and Management Prioritization Workshop for Medicinal Plants of Northwest Himalayan states of Jammu \& Kashmir, Himachal Pradesh and Uttaranchal. Bangalore: Foundation for Revitalisation of Local Health Traditions (FRLHT).

Castano, A. M., Vilà, M., and Sanchez, J. O. (2014). Pollination ecology of a plant in its native and introduced areas. Acta Oecol. 56, 1-9. doi: 10.1016/j.actao.2014. 01.001

Castro, S., Silveira, P., and Navarro, L. (2008). How flower biology and breeding system affect the reproductive success of the narrow endemic Polygala vayredae Costa (Polygalaceae). Bot. J. Linn. Soc. 157, 67-81. doi: 10.1111/j.1095-8339. 2008.00784.x

Chaurasia, O. P., and Ballah, B. (2009). Medicinal Plants of cold desert Ladakh used in treatment of stomach disorders. Indian J. Trad. Know. 82, $185-189$.

Dafni, A. (1992). Pollination Ecology. (Oxford: Oxford University Press), 1-57. 
Dafni, A., and Maués, M. M. (1998). A rapid and simple procedure to determine stigma receptivity. Sex. Plant Reprod. 11, 177-180. doi: 10.1007/s004970050138

De Hertogh, A. A., and Le Nard, M. (1993). The Physiology of Flower Bulbs: A Comprehensive Treatise on the Physiology and Utilization of Ornamental Flowering Bulbous and Tuberous Plants. Amsterdam: Elsevier Science Publishers, 617-682.

Dillon, M. E., and Dudley, R. (2014). Surpassing Mt. Everest: extreme flight performance of alpine bumble-bees. Biol. Lett. 10:20130922. doi: 10.1098/rsbl. 2013.0922

Dorji, T., Hopping, K. A., Meng, F., Wang, S., Jiang, L., and Klein, J. A. (2020). Impacts of climate change on flowering phenology and production in alpine plants: the importance of end of flowering. Agric. Ecosyst. Environ. 291:106795. doi: 10.1016/j.agee.2019.106795

Endress, M. E., and Bruyns, P. V. (2000). A revised classification of the Apocynaceae. Bot. Rev. 66, 1-56. doi: 10.1007/bf02857781

Evans, J. D., Pettis, J. S., Hood, W. M., and Shimanuki, H. (2003). Tracking an invasive honey bee pest: mitochondrial DNA variation in Noth American small hive beetles. Apidologie 34, 103-109. doi: 10.1051/apido:2003004

Fang, X., Turner, N. C., Yan, G., Li, F., and Siddique, K. H. M. (2010). Flower numbers, pod production, pollen viability, and pistil function are reduced and flower and pod abortion increased in chickpea (Cicer arietinum L.) under terminal drought. J. Exp. Bot. 61, 335-345. doi: 10.1093/jxb/erp307

Gallardo, R., Dominguez, E., and Munoz, J. M. (1994). Pollen ovule ratio, pollen size, and breeding system in Astragalus (Fabaceae) subgenus Epiglotis. A pollen and seed allocation approach. Am. J. Bot. 81, 1611-1619. doi: 10.1002/j.15372197.1994.tb11473.x

Gan, X., Cao, L., Zhang, X., and Li, H. (2013). Floral biology, breeding system and pollination ecology of an endangered tree Tetracentron sinense Oliv. (Trochodendraceae). Bot. Stud. 54:50. doi: 10.1186/1999-3110-54-50

Ganie, A. H., Tali, B. A., Khuroo, A. A., Nawchoo, I. A., and Rather, A. M. (2014). Rheum spiciforme Royle (Polygonaceae): a new record to the flora of Kashmir Valley, India. Natl. Acad. Sci. Lett. 37, 561-565. doi: 10.1007/s40009-0140279-7

Ganie, A. H., Tali, B. A., Reshi, Z. A., and Nawchoo, I. A. (2017). Stigmatic Movement Promotes Cross Pollination in Rheum webbianum Royle: an Important Endemic Medicinal Plant of Kashmir Himalaya. Natl. Acad. Sci. Lett. 40, 435-438. doi: 10.1007/s40009-017-0579-9

Gopalakrishnan, K. K., and Thomas, T. D. (2014). Reproductive biology of Pittosporum dasycaulon Miq., (Family Pittosporaceae) a rare medicinal tree endemic to Western Ghats. Bot. Stud. 55:15. doi: 10.1186/1999-311055-15

Gordo, O., and Sanz, J. J. (2010). Impact of climate change on plant phenology in Mediterranean ecosystems. Glob. Change Biol. 16, 1082-1106. doi: 10.1111/j. 1365-2486.2009.02084.x

Grant, V. (1971). Plant Speciation. New York, NY: Columbia University Press.

Hingston, A. B., and McQuilan, P. B. (2000). Are pollination syndromes useful predictors of floral visitors in Tasmania? Aust. Ecol. 25, 600-609. doi: 10.1111/j. 1442-9993.2000.tb00065.x

Hu, W. Q., Lu, H., Liu, W., Yuan, J. X., and Zhang, D. (2011). Paternity identification and genetic structure analysis of the wild population in Paeonia lactiflora Pallas (Paeoniaceae). Acta Hortic. Sin. 38, 503-511.

Huang, Y., Zhang, C. Q., Blackmore, S., Li, D.-Z., and Wu, Z.-K. (2006). A preliminary study on pollination biology of Omphalogramma souliei Franch. (Primulaceae), a species endemic to China. Plant Syst. Evol. 261, 89-98. doi: 10.1007/s00606-006-0430-0

Julien, Y., and Sobrino, J. A. (2009). Global land surface phenology trends from GIMMS database. Int. J. Remote Sens. 30, 3495-3513. doi: 10.1080/ 01431160802562255

Kao, T. C., and Cheng, C. Y. (1975). Synopsis of the Chinese Rheum. Acta Phytotax. Sin. 13, 69-82.

Kaur, G., Singh, B. P., and Nagpal, A. K. (2013). Phenology of Some Phanerogams (Trees and Shrubs) of North-western Punjab, India. J. Bot. 2013:712405. doi: $10.1155 / 2013 / 712405$

Khajuria, A. (2013). Conservation Biology of Three Overexploited Medicinal Plants of North-West Himalayan Region. Ph.D. thesis. Rajouri: Baba Ghulam Shah Badshah University.
Khajuria, A., Verma, S., and Sharma, P. (2011). Stylar movement in Valeriana wallichii DC.- a contrivance for reproductive assurance and species survival. Curr. Sci. 100, 1143-1144.

Khan, S., Kumari, P., Wani, I. A., and Verma, S. (2021). Pollination biology and breeding system of Vitex negundo L. (Lamiaceae), an important medicinal plant. Int. J. Plant Rep. Biol. 13, 77-82.

Korner, C. (2003). Alpine Plant Life, 2nd Edn. (Heidelberg: Springer), 101-119.

Korner, C. (2007). The use of 'altitude' in ecological research. Trends Ecol. Evol. 22, 569-574. doi: 10.1016/j.tree.2007.09.006

Korner, C., and Cochrane, P. M. (1983). Stomatal responses and water relations of Eucalyptus pauciflora in summer along an elevational gradient. Oecologia 66, 443-455. doi: 10.1007/BF00378313

Korner, C., Neumayer, M., Menendez-Riedl, S. P., and Smeets-Scheel, A. (1989). Functional morphology of mountain plants. Flora 182, 353-383.

Kumari, P., Khajuria, A., Wani, I. A., Khan, S., and Verma, S. (2020). Effect of floral size reduction on pollination and reproductive efficiency of female flowers of Valeriana wallichii, a threatened medicinal plant. Natl. Acad. Sci. Lett. 44, 75-79. doi: 10.1007/s40009-020-00954-8

Lewis, D. (1979). Sexual Incompatibility in Pants. London: Edward Arnold Publishers limited.

Li, A. R. (1998). Flora Republicate Popularis Sinicae. Beijing: Science press.

Li, I. Y., Kleunen, M. V., and Stift, M. (2019). Sibling competition does not magnify inbreeding depression in North American Arabidopsis lyrata. Heredity 123, 723-732.

Li, Q. J., Xu, Z. F., Kress, W. J., Xia, Y. M., Zang, L., and Deng, X. B. (2001). Flexible style that encourages outcrossing. Nature 410, 431-431. doi: 10.1038/3506 8635

Li, T., Liu, X., Li, Z., Ma, H., Wan, Y., Liu, X., et al. (2018). Study on Reproductive Biology of Rhododendron longipedicellatum: a Newly Discovered and Special Threatened Plant Surviving in Limestone Habitat in Southeast Yunnan, China. Front. Plant Sci. 9:33. doi: 10.3389/fpls.2018.00033

Linnaeus, C. (1753). Rheum ribes". Species Plantarum, Tomus I. Stockholm: Impensis Laurentii Salvii.

Mayer, C., Adler, L., Armbruster, W. S., Dafni, A., Eardley, C., Huang, S.-Q., et al. (2011). Pollination ecology in the 21st century: key questions for future research. J. Pollinat. Ecol. 3, 8-23. doi: 10.26786/1920-7603(2011)1

Mercado, J. A., Fernfindez-Mufioz, R., and Quesada, M. A. (1994). In vitro germination of pepper pollen in liquid medium. Sci. Hortic. 57, 273-281.

Moore, L. M., and Lauenroth, W. K. (2017). Differential effects of temperature and precipitation on early- vs. late-flowering species. Ecosphere 8:e01819. doi: $10.1002 /$ ecs 2.1819

Moza, K. M., and Bhatnagar, A. K. (2007). Plant reproductive biology studies crucial for conservation. Curr. Sci. 92:1207.

Mulik, N. G., and Bhosale, L. J. (1989). Flowering phenology of the mangroves from the West Cost of Maharashtra. J. Bombay Nat. Hist. Soc. 3, 355-339.

Nautiyal, B. P., Nautiyal, M. C., Rawat, N., and Nautiyal, A. R. (2009). Reproductive biology and breeding system of Aconitum balfourii (Benth) Muk: a high altitude endangered medicinal plant of Garhwal Himalaya, India. Res. J. Med. Plants 3, 61-68. doi: 10.3923/rjmp.2009.61.68

Neal, P., and Anderson, G. J. (2005). Are mating system breeding system of inconsistent and confusing terminology in plant reproductive biology. Or is the other way around. Plant Syst. Evol. 2501, 173-185. doi: 10.1007/s00606-0040229-9

Nebot, A., Cogoni, D., Fenu, G., and Bacchetta, G. (2016). Floral biology and breeding system of the narrow endemic Dianthus morisianus Vals. (Caryophyllaceae). Flora 219, 1-7. doi: 10.1016/j.flora.2015.12.004

Noy-Porat, T., Flaishman, M. A., Eshel, A., Sandler-Ziv, D., and Kamenetsky, R. (2009). Florogenesis of the Mediterranean geophyte Narcissus tazetta and temperature requirements for flower initiation and differentiation. Sci. Hortic. 120, 138-142. doi: 10.1016/j.scienta.2008.09.016

Ollerton, J. (2014). Sunbird surprise for syndromes. Nature 394, 726-727. doi: $10.1038 / 29409$

Pando, J. B., Tchuenguem, F. N., and Tamesse, J. L. (2011). Foraging and pollination behaviour of Xylocopacalens lepeletier (Hymenoptera: Apidae) on Phaseolus coccineus L. (Fabaceae) flowers at Yaounde (Cameroon). Entomol. Res. 41, 185-193. doi: 10.1111/j.1748-5967.2011.00334.x 
Phillips, N. C., Drost, D. T., Varga, W. A., and Shultz, L. M. (2011). Demography, reproduction, and dormancy along altitudinal gradients in three intermountain Allium species with contrasting abundance and distribution. Flora 206, 164171. doi: 10.1016/j.flora.2010.05.002

Pluess, A. R., Frei, E., Kettle, C. J., Hahn, T., and Ghazoul, J. (2011). Plant growth and fitness of Scabiosa columbaria under climate warming conditions. Plant Ecol. Divers. 4, 379-389. doi: 10.1080/17550874.2011.618848

Porch, T. G., and Jahn, M. (2001). Effects of high-temperature stress on microsporogenesis in heat-sensitive and heat-tolerant genotypes of Phaseolus vulgaris. Plant Cell Environ. 24, 723-731.

Pradervand, J. N., Pellissier, L., Randin, C. F., and Gusain, A. (2014). Functional homogenization of bumblebee communities in alpine landscapes under projected climate change. Clim. Change Resp. 1, 1-10.

Proctor, M., Yeo, P., and Lack, A. (1996). The Natural History of Pollination. Portland, OR: Timber Press.

Ramirez, N., and Nassar, J. M. (2017). Breeding systems in Angiosperms: novel inferences from a new analytical approach. Plant Syst. Evol. 303, 119-137. doi: 10.1007/s00606-016-1357-8

Rashid, S., Kaloo, Z. A., Singh, S., and Bashir, I. (2014). Medicinal importance of genus Rheum- A review. Int. J. Adv. Res. 2, 261-267.

Rathcke, B., and Lacey, E. P. (1985). Phenological patterns of terrestrial plants. Annu. Rev. Ecol. Syst. 6, 16-17. doi: 10.1146/annurev.es.16.110185.001143

R Core Team (2020). R: A Language and Environment for Statistical Computing. Vienna: R Foundation for Statistical Computing.

Rodriguez-Riano, T., and Dafni, A. (2007). Pollen-stigma interference in two gynodioecious species of Lamiaceae with intermediate individuals. Ann. Bot. 100, 423-431. doi: 10.1093/aob/mcl168

Rohde, A., and Bhalerao, R. (2007). Plant dormancy in the perennial context. Trends Plant Sci. 12, 217-223. doi: 10.1016/j.tplants.2007.03.012

Ruan, C., Li, H., and Mopper, S. (2009). Kosteletzkya virginica displays mixed mating in response to the pollinator environment despite strong inbreeding depression. Plant Ecol. 203, 183-193. doi: 10.1007/s11258-008-9525-8

Sagoo, M. I. S., and Farooq, U. (2011). Cytology of Rheum, a vulnerable medicinal plant from Kashmir Himalaya. Chrom. Bot. 6, 41-44. doi: 10.3199/is cb.6.41

Sajjad, A., Saeed, S., Muhammad, W., and Arif, M. J. (2009). Role of insects in crosspollination and yield attributing components of Sesbania sesban. Int. J. AgriC. Biol. 11, 77-80.

Schemske, D. W., and Lande, R. (1985). The evolution of self fertilization and inbreeding depression in plants. II. Empirical observations. Evolution 39, 41-52. doi: 10.1111/j.1558-5646.1985.tb04078.x

Shivanna, K. R. (2003). Pollen Biology and Technology. Enfield: Science Publishers.

Shivanna, K. R., and Rangaswamy, N. S. (1992). Pollen Biology - A Laboratory Manual. Berlin: Springer Verlag.

Shivanna, K. R., and Sastri, D. C. (1981). Stigma-surface esterase activity and stigma receptivity in some taxa characterized by wet stigmas. Ann. Bot. 47, 53-64. doi: 10.1093/oxfordjournals.aob.a086000

Siddique, M. A. A., Dar, N. A., Wafai, B. A., and Beigh, Y. S. (1997). Reproductive biology of Podophyllum hexandrum Royle (Podophyllaceae) an important, rare and threatened Himalayan medicinal plant. Proc. Natl. Acad. Sci. India Bhubaneshwar 10-11. doi: 10.15258/sst.2009. 37.1 .02

Singh, V. K., Barman, C., and Tandon, R. (2014). Nectar Robbing Positively Influences the Reproductive Success of Tecomella undulata (Bignoniaceae). PLoS One 9:e102607. doi: 10.1371/journal.pone.010 2607

Smitha, G. R., and Thondaiman, V. (2016). Reproductive biology and breeding system of Saraca asoca (Roxb.) De Wilde: a vulnerable medicinal plant. Springer Plus 5, 2-15. doi: 10.1186/s40064-016-3709-9

Sreekala, A. K. (2017). Importance of plant reproductive biology in conservation. Paper Presented at the National Conference on "Bioresources: Conservation, Utilization and Future Prospects"GRI-DU, Gandhigram, 4-5.

Srinivas, G., Babykutty, S., Sathiadevan, P. P., and Srinivas, P. (2007). Molecular mechanism of emodin action: transition from laxative ingredient to an antitumor agent. Med. Res. Rev. 27, 591-608. doi: 10.1002/med.20095

Stewart, R. R. (1972). An Annotated Catalogue of Vascular Plants of West Pakistan and Kashmir. (Karachi: Fakhri Printing Press), 1028.
Stinson, K. A. (2004). Natural selection favors rapid reproductive phenology in Potentilla pulcherrima (Rosaceae) at opposite ends of a subalpine snowmelt gradient. Am. J. Bot. 91, 531-539. doi: 10.3732/ajb.91.4.531

Stocklin, J., Kuss, P., and Pluess, A. R. (2009). Genetic diversity, phenotypic variation and local adaptation in the alpine landscape: case studies with alpine plant species. Bot. Helv. 119, 125-133. doi: 10.1007/s00035-0090065-1

Tabin, S., Kamili, A. N., Ganie, S. A., Zargar, O., Sharma, V., and Gupta, R. C. (2016). Genetic diversity and population structure of Rheum species in Kashmir Himalaya based on ISSR markers. Flora 223, 121-128. doi: 10.1016/j.flora.2016. 05.001

Tali, B. A., Ganie, A. H., Nawchoo, I. A., Wani, A. A., and Reshi, Z. A. (2014). Assessment of threat status of selected endemic medicinal plants using IUCN regional guidelines: a case study from Kashmir Himalaya. J. Nat. Conserv. 23, 80-89. doi: 10.1016/j.jnc.2014.06.004

Tandon, R., Shivanna, K. R., and Mohan-Ram, H. Y. (2003). Reproductive biology of Butea monosperma (Fabaceae). Ann. Bot. 92, 715-723. doi: 10.1093/aob/ mcg193

Tao, L. X., Tan, H. J., Wang, X., Cao, L. Y., Song, J., and Cheng, S. H. (2008). Effects of high temperature stress on lowering and grain-setting characteristics for Guodao 6. Acta Agron. Sin. 34, 669-674. doi: 10.3724/sp.j.1006.2008.00669

Ved, D. K., Kinhal, G. A., Ravi Kumar, K., Prabhakaran, V., Ghate, U., Vijaya Shankar, R., et al. (2003). Conservation Assessment and Management Prioritization for the Medicinal Plants of Jammu \& Kashmir, Himachal Pradesh \& Uttaranchal. Bangalore: Foundation for Revitalisation of Local Health Traditions.

Verma, S., Kaul, V., Magotra, R., and Koul, A. K. (2008). Pollinator induced anther dehiscence in Incarvillea emodii (Bignoniaceae). Curr. Sci. 94, 1372-1374.

Verma, S., Magotra, R., and Koul, A. K. (2003). Restoration of Eremostachys superba Royle ex Benth.- a critically endangered species. Curr. Sci. 84, 13071308.

Verma, S., Magotra, R., and Koul, A. K. (2004). Stylar movement avoids self and promotes cross-pollination in Eremurus himalaicus. Curr. Sci. 87, 872-873.

Vikas, T. R. (2011). Reproductive biology of Azadirachta indica (Meliaceae), a medicinal tree species from arid zones. Plant Species Biol. 26, 116-123. doi: 10.1111/j.1442-1984.2010.00311.x

Wani, I. A., Verma, S., Kumari, P., Charles, B., Hashim, M. J., and El-Serehy, H. A. (2021). Ecological assessment and environmental niche modelling of Himalayan rhubarb (Rheum webbianum Royle) in northwest Himalaya. PLoS One 16:e259345. doi: 10.1371/journal.pone.0259345

Yamasaki, E., and Sakai, S. (2013). Wind and insect pollination (ambophily) of Mallotus spp. (Euphorbiaceae) in tropical and temperate forests. Aust. J. Bot. 61, 60-66. doi: 10.1071/bt12202

Yaqoob, U., and Nawchoo, I. A. (2015). Impact of habitat variability and altitude on growth dynamics and reproductive allocation in Ferula jaeschkeana Vatke. J. King Saud Univ. Sci. 29, 1-9. doi: 10.1016/j.jksus.2015.10.002

Yaqoob, U., and Nawchoo, I. A. (2016). Reproductive ecology of an endangered monocarpic herbaceous perennial, Ferula jaeschkeana Vatke. Trop. Ecol. 57, $849-864$.

Conflict of Interest: The authors declare that the research was conducted in the absence of any commercial or financial relationships that could be construed as a potential conflict of interest.

Publisher's Note: All claims expressed in this article are solely those of the authors and do not necessarily represent those of their affiliated organizations, or those of the publisher, the editors and the reviewers. Any product that may be evaluated in this article, or claim that may be made by its manufacturer, is not guaranteed or endorsed by the publisher.

Copyright (C) 2022 Wani, Verma, Ahmad, El-Serehy and Hashim. This is an openaccess article distributed under the terms of the Creative Commons Attribution License (CC BY). The use, distribution or reproduction in other forums is permitted, provided the original author(s) and the copyright owner(s) are credited and that the original publication in this journal is cited, in accordance with accepted academic practice. No use, distribution or reproduction is permitted which does not comply with these terms. 